POLIIICAL ECONOMY RESEARCH INSIITUTE

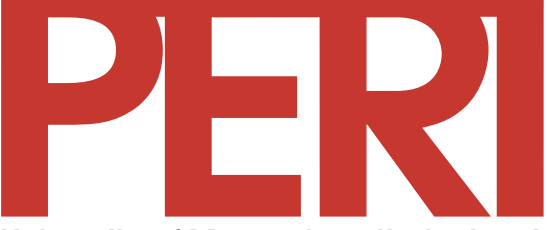

University of Massachusetts Amherst

\title{
The New Face of Unequal Exchange: Low-Wage Manufacturing, Commodity Chains, and Global Inequality
}

\author{
James Heintz
}

2003

Revised September 2003

10th floor Thompson Hall University of Massachusetts Amherst, MA, 01003-7510 Telephone: (413) 545-6355 Facsimile: (413) 545-2921

Email:peri@econs.umass.edu Website:

http://www.umass.edu/peri/

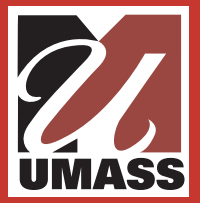




\title{
The new face of unequal exchange: low-wage manufacturing, commodity chains, and global inequality
}

\author{
James Heintz ${ }^{*}$
}

May 2003

Revised September 2003

\begin{abstract}
The institutional structure of global commodity chains and cross-border production networks has a profound impact on how the benefits of globalized production are distributed. This paper engages with this issue by developing a model that combines the insights of earlier unequal exchange theorists and new work on global commodity chains to clarify the distributive dynamics of the expansion of low-wage manufacturing in the developing world. In this framework, the ability of productivity-led development to raise employment incomes in low-wage manufacturing is constrained and depends on how the benefits of productivity improvements are captured - as lower prices for consumers or higher rents for brandname multinationals. In contrast, consumption-led growth in relatively affluent consumer markets will contribute to income convergence when demand for manufactured consumer imports is sufficiently income elastic. However, in the long-run, labor market, macroeconomic, and environmental constraints will likely compromise this form of export-led employment growth.
\end{abstract}

JEL Classification: F02, F23, O19

Keywords: $\quad$ trade, global commodity chains, multinational

corporations, subcontracting, branding, inequality.

\footnotetext{
Political Economy Research Institute, University of Massachusetts - Amherst (jheintz@peri.umass.edu). I would like to thank Samuel Bowles, Elissa Braunstein, Alper Duman, Gerald Epstein, Thomas Hertz, Robert Pollin, Mohan Rao, and Stephanie Seguino for insightful comments and suggestions on earlier drafts of this paper. All errors are mine.
} 


\section{Introduction}

Relying on consumer markets of affluent countries to provide the demand needed for export growth frequently involves new types of dependencies for low-wage manufacturing sectors. Large retail conglomerates, brand-name multinationals and intermediate buyers have more market power than small, competitive producers and subcontractors, affecting their ability to capture the benefits associated with an expansion of low-wage manufacturing. The institutional structure of global commodity chains and cross-border production networks matters a great deal for determining how the benefits of globalized production are distributed among the various players - from low-wage subcontractors to multinational corporations. Moreover, the nature of these relationships determines the effectiveness of a productivity-led strategy relative to a demand-led strategy for narrowing the income gap between high-income and low-income economies.

The "unequal exchange" tradition offered a trade-based explanation of divergent growth when developed countries specialized in industrial manufacturing and developing countries specialized in raw materials and primary products. Many of the insights of these earlier theoretical arguments can be applied to the structures of modern demand-driven commodity chains. However, whether these similarities produce the same outcome of trade-based divergent growth is the subject of on-going debate. This paper engages with this controversy by providing an alternative theoretical framework that combines the insights of earlier unequal exchange theorists and new work on global commodity chains in an effort to clarify the distributive dynamics of low-wage manufacturing in the developing world.

The paper is organized as follows. The second section provides a backdrop to the rest of the article by describing relevant trends in the globalization of production and consumption. It relates these issues to the earlier unequal exchange theories of divergent growth. In so doing, global commodity chain analysis is connected with the insights of the unequal exchange tradition. The third section presents a formal model, with a particular focus on branding and similar strategies of monopolistic competition in affluent consumer markets, on the one hand, and the intensely competitive conditions which subcontractors face, on the other. The model is used to explore how exogenous changes in the parameters of the model - e.g. productivity improvements - affect distributive outcomes along the commodity chain. The fourth section empirically investigates whether demand-driven export growth is likely to contribute to a narrowing or widening of income inequalities. The fifth section discusses the implications of this analysis for policy and a short summary concludes the paper.

\section{Global production, consumer economies, and unequal exchange}

The pattern of trade in manufactured goods has undergone a significant transformation in recent decades, with the broad composition of exports from less developed countries converging to that observed in advanced economies. Manufactured goods account for an increasing share of the exports of developing countries. Figure 1 documents these changes from 1970 to 2000. In the 1970s, manufacturing accounted for 
less than 20 percent of all exports of developing countries. By 2000, this proportion had risen to over 70 percent. Care must be taken in generalizing this trend. Much of the change was driven by key economies in East Asia and Latin America. Manufacturing remains underdeveloped in many of the poorest countries of the world. Nevertheless, the overall transformation is notable - developing countries are producing an increasing share of the world's manufactured exports.

Figure 1

Manufacturing exports as a percentage of total exports, developed and developing countries, 1970-2000.

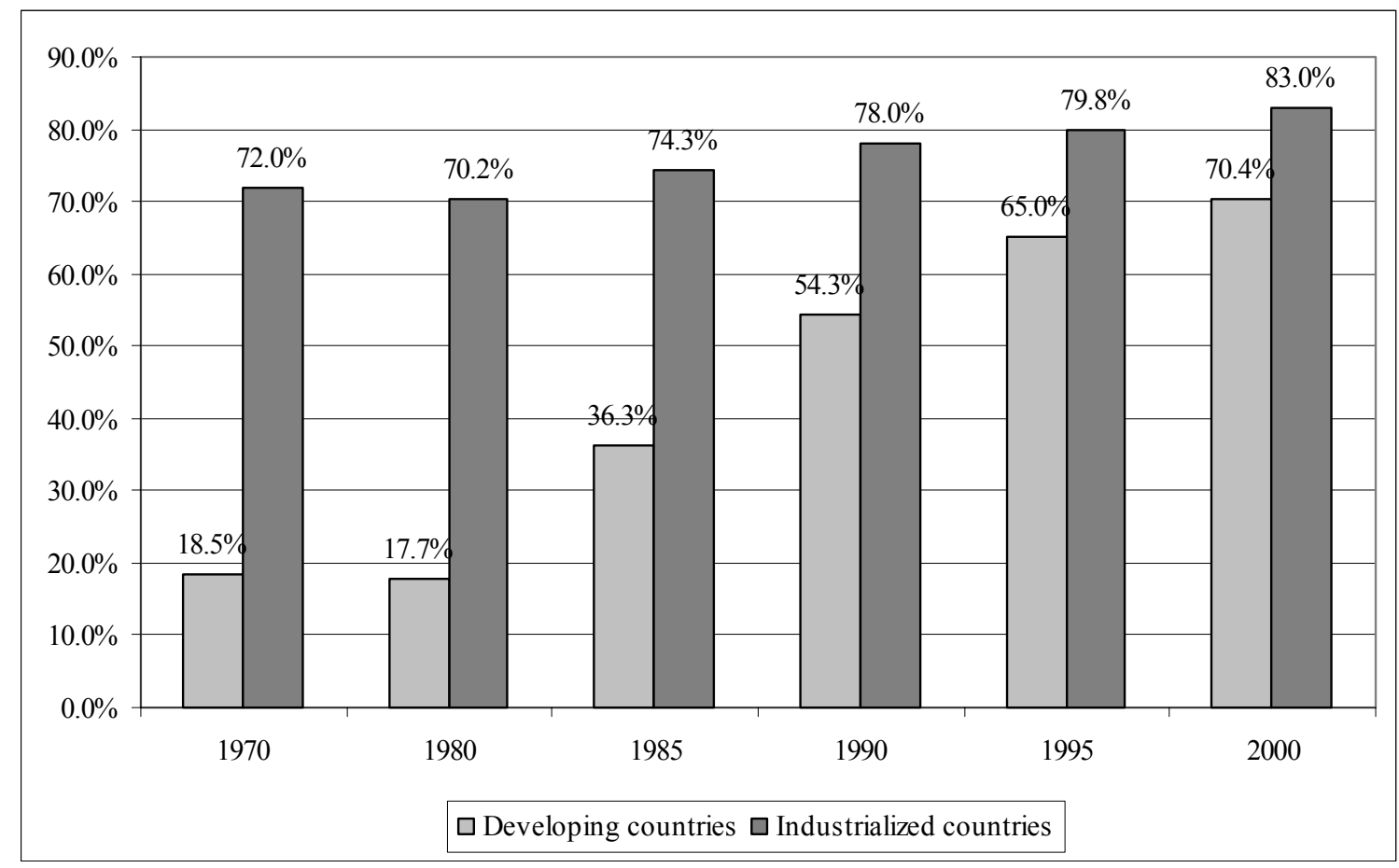

Source: United Nations, World Economic and Social Survey 2002, Table A14-15, pp. 300-3; World Economic and Social Survey 2000, Table A15, pp. 263-4; ILO, World Employment Report 1995 , Table 6, p. 33

The growth in manufactured exports contributes to an intensification of trade competition. Not only are developing countries competing with the established manufacturing sectors of advanced industrial countries, they also are competing with each other. Improving a country's global competitive position has emerged as a cornerstone of export-orient growth strategies in which expanding the export sector becomes the engine of industrial development. In addition, guaranteeing access to the markets of affluent economies has emerged as an obvious corollary to an export-led growth strategy.

The large consumer markets of North America, Western Europe, and Japan represent a vast source of purchasing power for manufactured exports. For example, U.S. imports of goods from non-OPEC developing economies increased from 23.0 percent of 
total imports of goods in 1978 to 44.6 percent by $2002 .{ }^{1}$ Over the same period, U.S. imports of capital goods, consumer goods, and automotive products as a share of all imported non-petroleum goods grew from 56.6 percent in 1978 to 78.8 percent in 2002. This mirrors the changing composition of exports from developing countries, away from agricultural goods, raw materials, and industrial supplies and towards manufactured goods.

In contrast to externally-focused, export-oriented industrialization, the historical expansion of manufacturing capacity in the advanced industrialized states has been linked to the development of domestic consumer markets. Studies of the industrial development of the U.S. and other Western economies prior to the 1970s have argued that both industrial wages and forms of social protection (e.g. income replacements and minimum wages) supported the aggregate demand necessary for maintaining profitability and investment (see, for example, Boyer and Juillard 2002, Glyn et al. 1990, Piore and Sabel 1984, Aglietta 1979: 151-208). The term fordism, after Henry Ford, is frequently used to describe the concurrent development of mass production and the domestic consumer market. Ford not only established productivity-enhancing methods of organizing production and labor processes, but also argued that workers should be paid wages high enough so that they could purchase the industrial products a country produced (Ford 1973: 116, 124-5). ${ }^{2}$ In a classical fordist analysis, the organization of production and consumption are mutually reinforcing. Mass production with wage increases proportional to productivity improvements supports a mass market which, in turn, sustains profits for further capital accumulation without triggering a crisis of underconsumption. ${ }^{3}$

For today's advanced economies, industrial development relied, in part, on the close tie between the expansion of production and the growth of domestic consumer markets. However, the globalization of manufacturing breaks this link. In most cases, the former logic linking mass production and domestic consumption no longer applies wages paid to workers in the export sectors of developing countries do not support purchasing power in affluent consumer markets. ${ }^{4}$

\footnotetext{
1 Author's calculations from U.S. international transactions data, Bureau of Economic Analysis, U.S. Department of Commerce. Developing countries include the countries of Latin America, Caribbean, Asia, and Africa, excluding Japan, Australia, New Zealand, and South Africa.

2 Ford himself raised wages overnight from an average of $\$ 2.34$ a day to $\$ 5.00$ a day in 1914 . However, a single employer acting alone can not significantly influence aggregate demand. One suggested motivation for this historic raise is that it would improve industrial relations and stave off conflictual collective action among workers (Raff 1988). Other possible explanations, in the spirit of the efficiency wage tradition, include a desire to reduce turnover, an effort to improve the average pool of workers, or an attempt to increase effort on the job.

3 Balancing wage increases with productivity growth can be seen as distinct from a "wage-led growth" regime in which higher levels of effective demand, brought about by increases in the share of aggregate output going to labor, raises growth rates. Whether higher real wages lead to faster growth depends on whether household consumption due to larger labor incomes offsets a potential fall in investment due to lower profit rates (Bowles and Boyer 1995).

4 Some have criticized the fordist analysis for ignoring other crucial factors that helped develop mass consumer markets. For example, Medeiros (2000) has emphasized the role that marketing, product innovation, and access to credit had in establishing the American pattern of mass consumption as early as the 1920s. As globalized production weakens the connection between wages paid at the point of production
} 
Despite the breakdown of coordination between domestic production and consumption, the importance of the expansion of mass consumer markets in countries like the U.S. has not waned with domestic deindustrialization and the growth of global manufacturing (Boyer and Julliard 2002). The expansion of consumer-based industries provides a source of new, often low-wage, jobs in the relatively affluent economies of the global North. It is hard to deny that "Big Retail" plays an increasingly influential role in many advanced economies. Perhaps most symbolically, in 2002 Wal-Mart surpassed General Motors as the largest U.S. corporation in terms of sales volume. ${ }^{5}$ More generally, according to the U.S. Bureau of Labor Statistics, manufacturing employment fell 9 percent from 1980 to 2000 while retail employment increased 55 percent.

This growth in retailing occurred despite pressures on domestic wage incomes. Beginning in the 1970s falling real wages in the U.S. and rising unemployment in Western Europe raised questions about the ability of wage income to support increasing levels of consumption. Nevertheless, the expansion of consumer spending remains an important contributor to the growth of these economies. How can a consumer economy be sustained in the context of falling real wages or growing unemployment?

The case of the U.S. economy is particularly instructive in this regard. There are three important developments which helped industries dependent on American consumerism to expand, despite the decline in hourly real wages: (1) more hours of paid work, especially among women; (2) the continued expansion of consumer credit (including the rapid expansion of credit for purchase of non-durables); and (3) the growth in low-cost imports of particular goods which allowed prices to fall and demand to rise.

Average annual hours of paid work per employee were stable from the end of World War II through the 1960s in the U.S., but they began to climb thereafter (Schor 1992). The trend towards longer hours continues today (Mishel, Bernstein, and Schmitt 2001). ${ }^{6}$ Much of this growth can be accounted for by increases in the hours of paid work performed by women. Longer hours help maintain family incomes and consumer purchasing power despite lower hourly wages. During this same period, household debt, including debt used to purchase consumer goods, was on the rise. Between 1989 and 1998 average credit card debt increased by 54 percent. By 1998, stocks of debt had risen to such a level that average payments on total household debt reached 17.6 percent of family income (Kennickell et al. 2000, Kennickell and Starr-McCluer 1994). These increases in consumer credit support higher levels of effective demand for goods.

However, it is the impact of low-wage imports on the relative price of tradable goods and the concurrent expansion of consumer economies in advanced industrialized

and the effective demand in affluent consumer markets, these factors identified by Medeiros have become increasingly important in extending mass consumption.

5 See New York Times, April 1, 2002, p. 1. Prior to becoming the largest corporation on the basis of sales, Wal-Mart was already the largest single employer in the U.S.

6 For example, between 1989 and 1998 average annual hours worked increased by 4.3 percent for married couple families with children. Hours had already increased by 6.1 percent from 1979 to 1989 (Mishel, Bernstein, and Schmitt 2001: 93-108). 
nations that is of particular relevance to the arguments presented here. Consumers in affluent nations benefit from low-wage imports when retail prices fall for the goods they purchase. To see this, consider the example of U.S. clothing imports and retail prices. Figure 2 illustrates trends in the relative price of clothing since 1958, measured as the consumer price index for clothing divided by the consumer price index for other goods, excluding the volatile components of food and energy prices. ${ }^{7}$ Beginning in the early 1970 s, the price of clothing for U.S. consumers relative to a broad index of prices for other goods began to fall and it continued to decline throughout the remainder of the $20^{\text {th }}$ century. Figure 2 also shows the value of clothing imports as a fraction of domestic clothing production over the same period. The growth of clothing imports relative to domestic production began to accelerate in the early 1970s, at the same time that relative prices began to come down. These empirical trends support the argument that low-cost imports contributed to the reduction of retail clothing prices in the U.S. ${ }^{8}$

Figure 2.

Import penetration and the relative price of apparel in the U.S., 1958-2000.

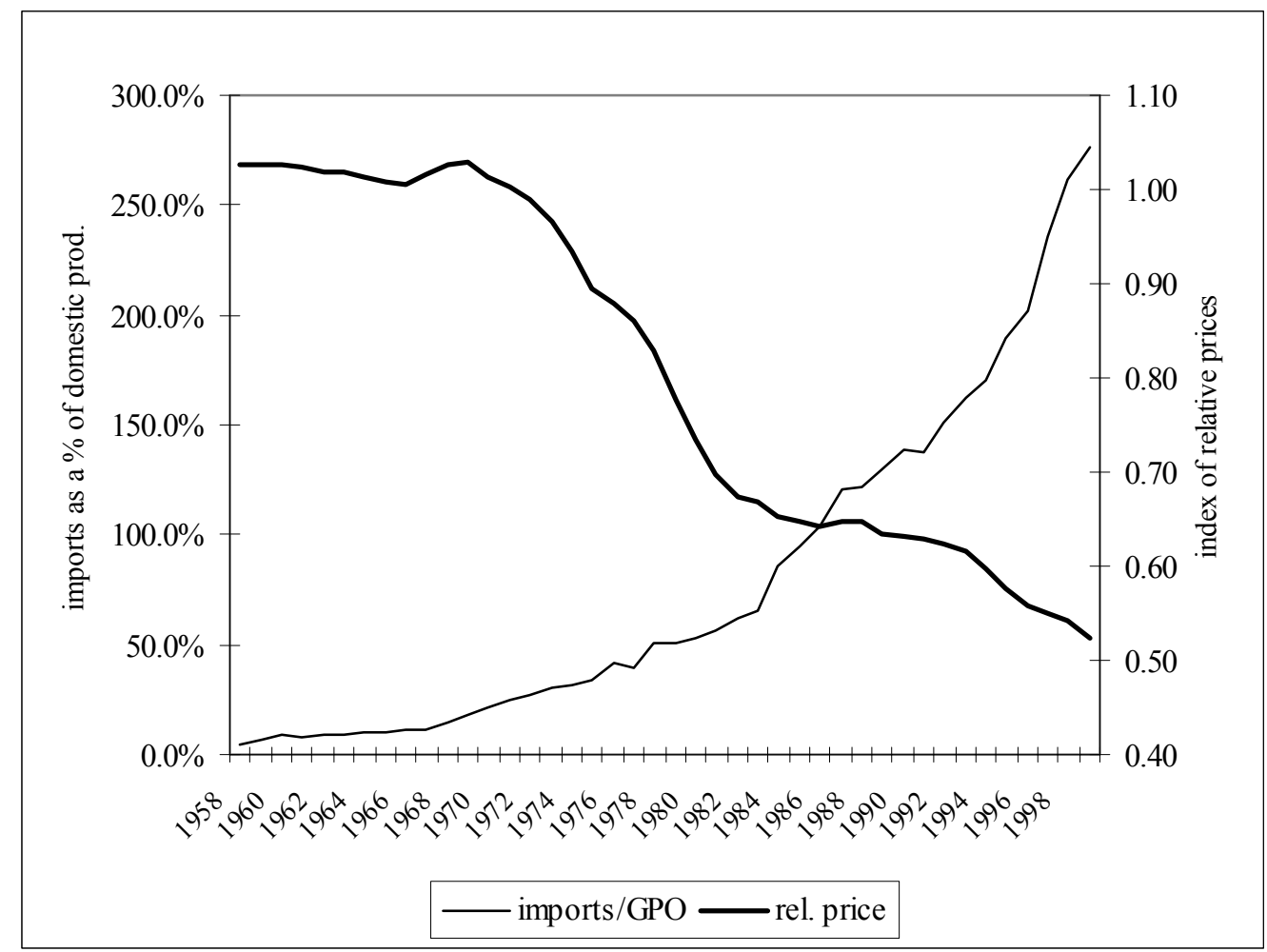

Source: For the relative price of apparel: U.S. Bureau of Labor Statistics. For imports of apparel: U.S. Census Bureau, U.S. International Trade in Goods and Services, various years. For domestic production of apparel (GPO): Bureau of Economic Analysis, U.S. Department of Commerce. Note: data includes both wearing apparel and footwear.

\footnotetext{
7 Using the CPI which included food and energy prices does not change the trend illustrated in Figure 2 in any meaningful way.

8 The two time series illustrated in Figure 2 are non-stationary. Cointegration analysis of the two series suggests a long-run equilibrium relationship exists between clothing imports relative to domestic production and the relative consumer price of clothing. These results are available from the author upon request.
} 
In 1995, U.S. consumers purchased an average of 28.7 new outerwear garments annually; in 1967, the number was just 14.1. Over the same time period, clothing's share of average consumer expenditures dropped from approximately 10 percent to 5.5 percent (Abernathy et al. 1999: 4-5). Growth in household incomes could account for this shift. However, according to the U.S. Census Bureau, median real household incomes in the U.S. rose by just 14 percent and mean real household incomes rose by 34 percent over the same time period (U.S. Census Bureau 2000: B-3). These changes in income are insufficient to simultaneously account for a doubling of per capita garment purchases and a halving of expenditure share. Therefore, falling relative prices must explain a large portion of the consumption boom. ${ }^{9}$

Trade theory in the Heckscher-Ohlin/Stopler-Samuelson (HOSS) tradition provides an explanation of these trends. Developing countries, with an abundance of inexpensive labor and a relative scarcity of fixed capital assets, will specialize in lowwage production while advanced industrialized countries will concentrate on industries using capital- and technology-intensive techniques. Under conditions of unrestricted trade, the relative prices of goods adjust so that prices of labor-intensive products will fall in high-income, high-tech countries.

However, the HOSS tradition does not incorporate an analysis of the institutions that structure modern networks of production, distribution, and consumption. Instead, HOSS theories focus on seamlessly mapping the movement of relative factor and output prices and thereby abstract from the institutional structure of trade networks. The HOSS analysis also excludes consideration of the macroeconomic environment and simply assumes full-employment. The dynamism of consumer economies in the global North has a profound impact on the growth of globalized manufacturing. Given the de-linking of production and consumption on a global scale, the invocation of Say's Law - supply will create its own demand - becomes a questionable assumption.

By pushing aside the institutional structure of international trade networks, the HOSS approach concludes that the optimal strategy for developing economies with an abundance of low-wage labor is to specialize in the production of low-cost, laborintensive exports. However, this type of industrial specialization could push developing countries onto a low-wage, low-productivity growth path. Recent experience suggests that a low-road strategy is not the only option. Several countries, most notably the newly industrializing economies of East Asia, have successfully pursued interventionist trade and industrial policies that have allowed them to move up the industrial development ladder. These types of interventions confound the logic of the HOSS approach in which interventions into the process of specialization and free-trade produce distortions and undesirable outcomes. Because of these short-comings, a theoretical approach to

9 Empirical studies of the income elasticity of real clothing expenditures have found that clothing demand is inelastic - e.g. one point estimate of the income elasticity is approximately 0.50 while the estimate of the long-run price elasticity is -1.0 (Mokhtari 1992). Therefore, given the changes in average income, per capita U.S. clothing purchases should have grown by approximately 7 to 17 percent. For real clothing purchases to have doubled, falling relative prices must have played a critical. 
international trade is needed that specifically incorporates an analysis of the institutional setting in which global exchanges take place.

A different approach to international trade - the "unequal exchange" tradition provides an alternative framework for examining the distributive consequences of the context in which global exchange occurs. The spirit of this earlier literature is reflected in a new theoretical framework that is frequently called "global commodity chain" analysis. ${ }^{10}$ This approach specifically looks at the organization of global networks that have arisen with the internationalization of manufacturing. The innovations of global commodity chain analysis and the established insights of the unequal exchange tradition can be combined to shed light on the distributive implications of the new patterns of globalized consumption and low-wage manufacturing.

The term "unequal exchange" was coined by Arghiri Emmanuel (1972) in his theoretical exposition of the trade relationship that existed between the "core" and the "periphery". In particular, he provides an explanation of the growing inequalities that have been observed in the terms of trade between developing countries and the advanced industrialized economies. Although using distinct theoretical approaches, earlier works by Raúl Prebisch (1950), W. Arthur Lewis (1954), and Hans Singer (1950) formed the foundation of a broader unequal exchange tradition, in that they offered different structural explanations for observed inequalities in international trade. Emmanuel's evocative name for his approach to the core-periphery trade relationship captures the spirit of this rich theoretical tradition.

These schools of thought directly challenged the economic logic of the original conceptualization of an international division of labor in which the industrialized world produced manufactured goods while the developing world specialized in primary products and raw materials. This arrangement was justified on the grounds of efficiency and comparative advantage - a lack of specialization would reduce global income and lead to Pareto inferior outcomes. Therefore, developing countries should be content with the existing international division of labor since a move towards industrial production would jeopardize the efficiency gains of specialization. However, observed patterns in the terms of trade during the first half of the $20^{\text {th }}$ century directly contradicted this optimistic picture. The unequal exchange tradition explained these empirical trends and offered a theoretical alternative.

The unequal exchange tradition remains relevant today. Many of the characteristics of modern international production and trade networks reflect the conditions identified by the unequal exchange literature. Three aspects are particularly relevant:

10 "Global commodity chains," "global production networks," "supply chains", and "filière" all refer to similar methods of analysis. For one perspective on the differences between these approaches, see Henderson et al. (2002). 
(1) flexibility in sourcing decisions mimics the effect of capital mobility in the sense that competitive pressures limit the scope for subcontractors to raise production costs without triggering a substantial loss of output;

(2) oligopolistic, or monopolistic, structures in advanced economies are explicitly linked to competitive conditions in developing country manufacturing; and

(3) a surplus of labor exists at the point of production such that an expansion in output does not bid up wages.

In many respects, these characteristics reflect aspects of the unequal exchange theories of Emmanuel, Prebisch, and Lewis, respectively. Not surprisingly, these factors exert a strong influence over the distributive outcomes under the new international division of labor in a way that is not adequately captured by the HOSS model and other frameworks that emphasize the movement of product prices and factor costs alone. In demonstrating the relevance of these three approaches to what I am terming the unequal exchange tradition - Prebisch-Singer, Lewis, and Emmanuel - it helps to summarize each of their key arguments in turn.

The work of Raúl Prebisch and Hans Singer is often taken as representing one particular approach in the unequal exchange tradition. The Prebisch-Singer framework locates the determinants of the trade-based inequalities between the North and South in the differences that exist in the product and factor markets of the developing and industrialized countries. The industrialized manufacturing centers were able to translate productivity gains into higher incomes in terms of profits or payments to factors of production, while producers of primary products lost the benefits of productivity improvements to lower prices.

Two factors contributed to this dynamic in the Prebisch-Singer analysis. First, the institutions of the industrial North have sufficient market power to cause prices and wages to be stickier than is the case in the developing world where greater flexibility prevails. Second, the income elasticity of demand for manufactured goods tends to be higher than that of primary goods. Therefore, demand for manufactured goods will respond vigorously to productivity improvements that raise incomes. However, the demand for primary goods responds weakly (or possibly even negatively) to technological innovations. Therefore, during periods of productivity-led growth, prices of manufactured goods will rise relative to prices of primary products. Since primary commodities also tend to be price inelastic, the income terms of trade - that is, receipts from exports relative to imports - will also fall, leading to a widening income gap between industrialized and developing countries. ${ }^{11}$

\footnotetext{
11 The notion of "immiserating growth" proposed by Jagdish Bhagwati (1952) shares some analytical features with the Prebisch-Singer tradition. In Bhagwati's model, real economic growth can be associated with declining domestic consumption (real per capita income) under certain conditions. This occurs when increases in productivity produce a reduction in the terms of trade such that total consumption of imported goods actually falls. This is likely to happen when domestic production of imported goods is small and demand for imports is price inelastic.
} 
In contrast with the Prebisch-Singer approach to unequal exchange, W. Arthur Lewis focused on differences in the structure of the labor markets - in particular, the existence of a substantial surplus of labor in the developing world. In his framework, the price of labor in a labor surplus economy corresponds to the subsistence wage and labor demand can increase substantially without bidding up wages. Capital accumulation raises productivity, but in a labor surplus situation wages do not increase. Therefore, unit labor costs fall when productivity improves, leading to lower prices or higher profits. In an open economy framework, productivity improvements in the export sector of a labor surplus economy do not raise wages and incomes. Instead, the gains from productivity are lost in the form of deteriorating terms of trade. The benefits accrue to industrial purchasers and, potentially, the consumers in industrialized countries.

Emmanuel uses a markedly different approach to the problem of unequal exchange. In essence, Emmanuel applies the transformation problem of Marx to the realm of international trade. Profit rates are equalized across national boundaries due to the mobility of capital. In contrast, labor is mobile nationally, but immobile internationally. National wage levels are taken as independent, exogenous variables, determined by a range of historical and institutional factors. Under conditions of complete specialization, the free circulation of capital produces a situation in which developing countries with low wages suffer a disadvantage in international trade since they export goods produced with a given quantity of labor in exchange for imports from more industrialized countries produced with relatively less labor. This occurs because the price of the imports they purchase must cover both the relatively high wage of the industrialized workers and the equalized profit rate.

Despite theoretical differences, the unequal exchange tradition provides a collection of valuable insights into the problem of deteriorating terms of trade in developing countries. However, these models address an international division of labor in which manufactured goods are exported from the industrial North while developing countries specialize in primary products. It is unclear whether the unequal exchange tradition applies to the new international division of labor, in which developing countries are becoming prominent exporters of manufactured goods.

Recent research has produced evidence suggesting that developing countries have experienced deterioration in the commodity, or net-barter, terms of trade (i.e. the price of exports relative to the price of imports) of their manufacturing export sectors $v i s-\grave{a}$-vis the manufacturing sectors of the advanced industrial economies (UNCTAD 2002, Maizels 2000, Sarkar and Singer 1991). Others have found little evidence of a negative trend in the commodity terms of trade for manufactured exports, frequently describing the observed pattern over time as trendless (Athukorala 2000, 1993). However, the commodity terms of trade do not take into account the fact that manufactured exports from developing countries have expanded rapidly in recent years. Declining or trendless commodity terms of trade are consistent with rising income terms of trade which incorporate changes in the volume of exports (Athukorala 1993). 
Shifts in the international division of labor raises the question of whether comparing the terms of trade between identical manufacturing sectors is the relevant comparison. For example, a measure of the terms of trade between manufacturing in developing countries and an index of traded services and complex manufacturing in advanced economies found that the commodity terms of trade of developing economies had deteriorated since 1960 (Minford, Riley, and Nowell 1997). Similarly, the barter terms of trade of manufactured goods from developing countries relative to exported machinery, transport equipment, and services from developed economies has been declining from 1975-95 (Wood 1997).

In addition to empirical research on manufacturing terms of trade, growing attention has been paid to the global institutional connections that shape patterns of international industrial production, distribution, and consumption. A prime example is global commodity chain analysis which has been put forward by Gary Gereffi and others as a means of understanding the organization and relative influence of different players in global production systems (Gereffi 1994, 1999; Kaplinsky 2000; Henderson et al. 2003). Global commodity chain analysis attempts to explain how the transnational organization of production operates and evolves. Instead of focusing only on the movement of the relative prices of imports and exports, it also incorporates issues of structural differences, dependency, and the nature of retail and consumer markets. For example, in a buyerdriven commodity chain, large retailers or brand-name corporations set up a decentralized system of production and distribution. ${ }^{12}$ Actual production is subcontracted out to small producers who face extremely competitive conditions (Carr, Chen, and Tate 2000, Bonacich and Appelbaum 2000, Gereffi 1994). Retailers and brand-name multinationals enjoy some degree of market power which they can use to keep prices low for the goods they purchase or to earn rents through the development of monopolistic brand identities.

By combining the specific insights of global commodity chain analysis with the theoretical innovations of the unequal exchange traditions, a model of these relationships can be developed that explores the distributive consequences of the expansion of globalized manufacturing tied to affluent consumer markets through the institutional linkages of global commodity chains. Such a model can then be used to analyze the implications for manufacturing workers of changes such as productivity enhancements in low-wage export sectors, the expansion of consumerism in the affluent markets of the global North, or specific policy interventions to move towards sustained egalitarian growth.

\footnotetext{
12 Buyer-driven commodity chains can be contrasted with producer-driven commodity chains in which large manufacturing enterprises set up a system of global production. The relatively capital-intensive manufacture of automobiles, aircraft, and electrical machinery can be thought of as examples of producerdriven commodity chains. The literature on fragmentation, which explores the expansion of trade in intermediate goods as one aspect of globalized production, also best describes global production networks that are established between manufacturing firms (see, for example, Jones 2000 or the collection edited by Arndt and Kierzkowski 2001).
} 


\section{Commodity chains, branding, and distribution: a model}

One of the key features of global commodity chain analysis is the differences in market power that are evident as we move along the chain. Subcontractors and direct producers face highly competitive conditions while brand-name multinationals and large retailers enjoy a much higher degree of monopolistic influence. Unlike earlier discussions of unequal exchange and declining terms of trade which attributed differences in market structure to differences in the products themselves (e.g. primary commodities versus manufactured or finished goods), in a modern commodity chain changes the nature of the product itself cannot directly explain different degrees of market power. The sneaker purchased in a U.S. suburb is, at least physically, the same sneaker that was shipped from Indonesia. However, modern retailing exhibits economies of scale in influencing consumer psychology and in the consolidation of extensive supply networks. Therefore, the relative market power enjoyed by retailers and brand-name producers is derived from two sources: (1) branding and similar forms of monopolistic competition that shape consumer preferences and (2) competitive sourcing.

Retailers and multinational producers earn rents in global commodity chains by differentiating their products and pursuing strategies to limit the availability of close substitutes. The model developed below will focus on one common strategy of monopolistic competition in affluent consumer markets - branding. For the purposes of this discussion, I define branding to be the general process of product differentiation and identity-building that gives retailers and brand-name producers a higher degree of market power than would otherwise be the case. The benefits of branding can be substantial, especially when firms are selling relatively generic products - a pair of shoes, underwear, a t-shirt or a cup of coffee. By creating the space to charge higher prices, firms realize substantial rents that would be impossible to sustain in a perfectly competitive environment for generic products. However, competitive conditions prevail among subcontractors who are unable to pursue similar monopolistic strategies since they lack direct retail capacity and access to consumer markets. The products themselves are not the source of market power, the brand is. ${ }^{13}$

The relative market power of retailers and brand-name multinationals is also derived from their position as single, large buyers. Firms that have consolidated their supply and distribution networks on a national scale have a greater degree of leverage in enforcing a purely competitive environment at the level of actual production. Large retailers can credibly threaten to drop a particular supplier and source from another subcontractor elsewhere in the world - thereby insuring that they enjoy competitive prices. In this respect, consolidation of distribution and buying channels has been a key dynamic behind the competitive strategies and rapid growth of corporate discount retailers such as Wal-Mart and Target.

13 For an analysis of modern patterns of branding, see Klein (2002). Klein describes the extent of branding and it's tendency to expand into previously uncharted areas: celebrity endorsements, public spaces, sponsorships of concerts, art exhibits, and sporting events, and the U.S. education system, from elementary schools up to research universities. 
The highly competitive environment among subcontractors implies that competition among producers in developing countries effectively becomes competition among unit labor costs (UNCTAD 2002, Rodrik 1997). Therefore, the model developed here assumes that producers cannot raise unit production costs without drastically reducing output. These competitive conditions exist alongside labor markets which are characterized by surplus labor and substantial queuing for new employment opportunities. Under such conditions, incomes among low-skill workers in export production will not differ substantially from that which could be earned in other types of equivalent paid employment. ${ }^{14}$

We can develop a model of a global commodity chain that captures these characteristics of modern retailing and brand-name multinational production. To start, we can disaggregate the retail price, $\mathrm{P}$, of a particular product into shares received by each of the prime players in the core commodity chain: (1) the retailers or brand-name corporations, (2) the intermediaries (sometimes called "jobbers") which coordinate subcontracted production on behalf of the retailers and brands, and (3) the subcontractors who actually produce the goods. Due to the competitive conditions facing subcontractors and the existence of surplus labor, unit labor costs are assumed to be equalized across producers. We can break down the price components as follows:

$$
\text { (1) } P=\alpha(b)+r P+e(1+z)\left(\frac{w}{t}\right)
$$

in which $\alpha$ represents the gross per unit monopoly rents due to branding (assumed to be increasing a decreasing rate), $b$ represents the extent of branding activities (advertising, endorsements, promotions, sponsorships, media strategies), $\mathrm{r}$ is the percentage of the retail price going to intermediaries, e is the exchange rate (with local currency units in the denominator), $\mathrm{z}$ is the exogenously given competitive profit margin for subcontracted producers, $\mathrm{w}$ is the average wage per worker, ${ }^{15}$ and $\mathrm{t}$ represents labor productivity (output per employee). This expression represents a version of variable mark-up pricing at the retail level in which a firm's ability to bid up prices depends on its investment in branding activities. ${ }^{16}$

\footnotetext{
14 Empirical evidence supports this theoretical assumption. For example, a survey of labor market outcomes among women working in maquiladoras in Tijuana found that the addition of these new jobs did not lead to an improvement in the wage incomes of these workers relative to what they could have earned in informal work arrangements, although the volatility of income flows was reduced (Fussell 2000).

15 For informal and home-based production, employment may not be structured as a wage relationship. If these workers are paid their unit labor cost, then their wage equivalent could be calculated as the piece-rate multiplied by labor productivity. This wage equivalent could be substituted in the above expression wherever w appears.

16 In this respect, the model differs from monopolistic competition models in the Robinson-Hicks tradition in which price is determined by the firm's optimization decisions given a particular degree of market power. In this model, the firm effectively chooses a degree of market power, thereby determining per unit rents, by its level of investment in branding.
} 
Solving Equation 1 for P gives us the following expression for the retail price:

$$
\text { (2) } P=\frac{1}{(1-r)}\left[\alpha(b)+e(1+z)\left(\frac{w}{t}\right)\right]
$$

Some immediate accounting relationships can be derived from this expression. For example, higher monopoly rents due to branding activities will bid up the retail prices. Likewise, if intermediaries ( $\mathrm{r}$ ), subcontractors $(\mathrm{z})$, or production workers $(\mathrm{w})$ are able to increase their claims on income within the commodity chain, ceteris paribus, retail prices will increase. However, an increase in labor productivity (t) will lower retail prices. This raises the possibility that productivity improvements at the level of production will not be captured by the workers or the subcontractors themselves - the benefits will be passed up the commodity chain. I will return to this point later.

Since market power is concentrated at the level of the retailer or brand-name producer, it makes sense to model the decision-making process of these firms and trace the consequences through the commodity chain. The firms are assumed to choose the extent of branding (b) to maximize the total value of net rents they can capture in the retail market:

$$
\text { (3) } \max _{b} \alpha(b) \delta(P, Y)-c \delta(P, Y)-\mu(b)
$$

in which $\delta(\mathrm{P}, \mathrm{Y})$ represents the demand for the branded commodity as a function of price and income, $\mathrm{Y}$ represents disposable income, $\mathrm{c}$ is the constant per unit cost of retailing, and $\mu$ is the cost of branding, assuming increasing marginal costs. Two factors contribute to the total rents the firm enjoys - the rents they receive for the branded commodity and the level of consumer expenditures, which are dependent on prices and incomes.

Note that the level of branding is not included in the consumer demand function, although a case could be made that branding also influences the quantity demanded. However, including branding in the demand function does not change the fundamental logic of the model in any meaningful way, particularly in terms of the issues I focus on here. Therefore, for simplicity of exposition, demand in affluent markets is assumed to depend on only income and price.

The first-order condition for maximization is:

$$
\alpha_{b} \delta(P, Y)+(\alpha-c) \delta_{P}\left(\frac{\alpha_{b}}{1-r}\right)-\mu_{b}=0
$$

We can divide this expression into two parts that have a more intuitive interpretation. The first part represents the net marginal benefits of branding:

(5a) $B^{\prime}=\alpha_{b} \delta(P, Y)-\mu_{b}$ 
This expression indicates the value of the rents that would be enjoyed by increasing the extent of branding less the costs of doing so. For example, by investing more into name recognition, brand presence, endorsements, and image enhancement, firms will be able to raise the price of their products while maintaining a competitive position.

The second part of Equation 4 represents the indirect marginal costs of branding:

$$
\text { (5b) } C^{\prime}=-(\alpha-c) \delta_{P}\left(\frac{\alpha_{b}}{1-r}\right)
$$

While branding raises rents, it also raises retail prices (from Equation 2) and reduces demand. A decline in consumer expenditures will reduce total rents, even though rents per unit sold could be increasing. This dynamic places constraints on the extent to which firms can raise prices and capture additional rents. At some point consumers will stop buying. The above expression for the indirect marginal costs of branding captures this effect, adjusted for changes in the actual costs of retailing. When net marginal benefits equal the indirect marginal costs, the firm is practicing its optimal branding strategy (as expressed in Equation 4).

We can illustrate these relationships graphically. Figure 3 shows the net marginal benefit curve $\left(\mathrm{B}^{\prime}\right)$ and the indirect marginal cost curve $\left(\mathrm{C}^{\prime}\right)$ as a function of the amount of branding a firm undertakes. For interested readers, the derivation of slope is included in Appendix A. The intersection of these two curves represents the optimal strategy for the firm ( $b^{*}$ in the graph).

Figure 3

Marginal benefits, marginal costs, and optimal level of branding.

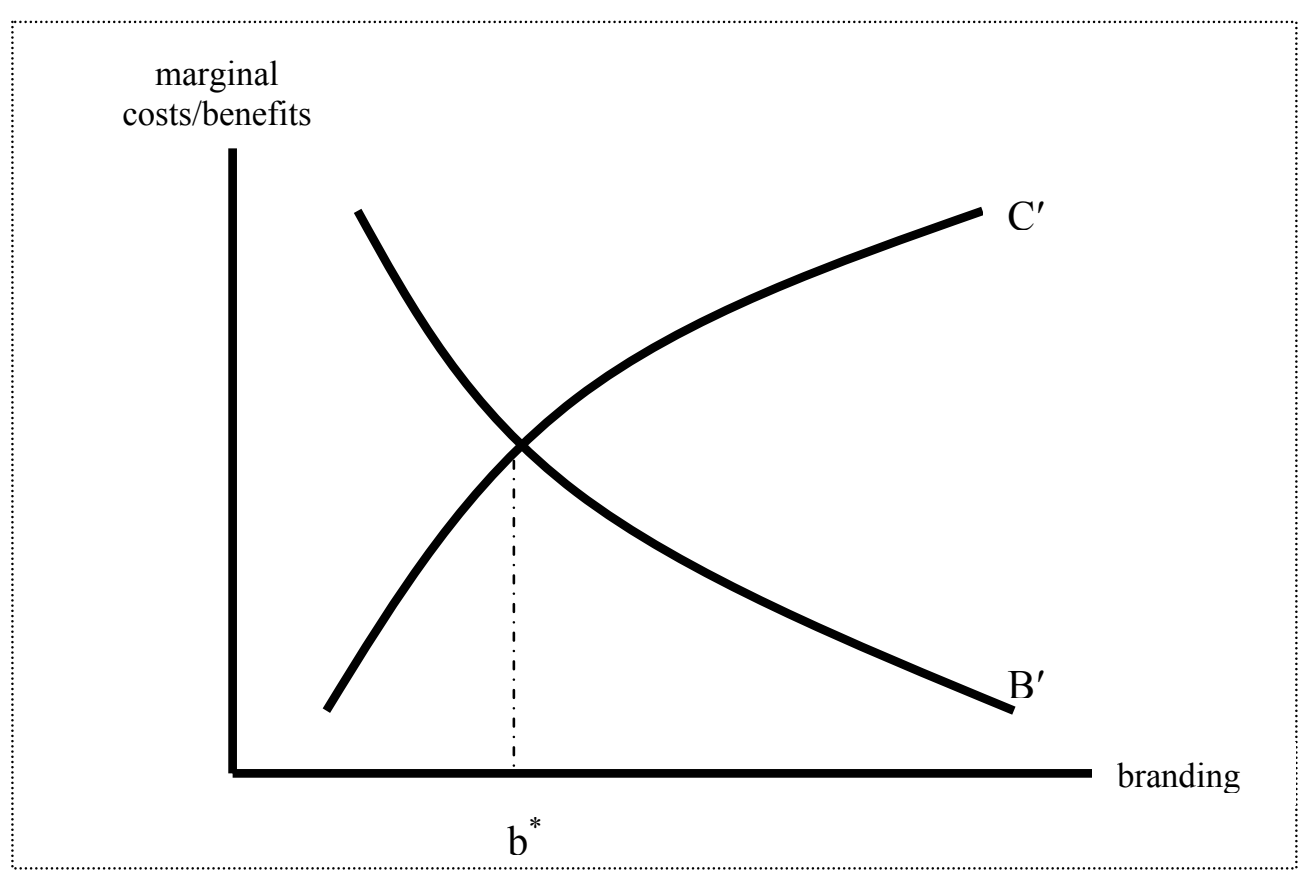


How would the company's strategy respond to an exogenous shift in one of the distributive parameters of the model? For example, what would happen if a country suddenly became more attractive due to the availability of lower cost labor raising from an exogenous change in trade policy, greater domestic political stability, an exchange rate depreciation, or a general expansion of the global sourcing network? The four-quadrant diagram in Figure 4 illustrates the various effects. From Equation 2 we know that, at a give level of branding, retail prices will be reduced while per unit rents, as given by the function $\alpha(b)$, remain the same. Since prices are reduced at each level of branding, demand will increase, thereby causing the marginal benefit curve to shift to the right, from $\mathrm{B}^{\prime}$ to $\mathrm{B}^{\prime \prime}$, as illustrated in the upper-right frame of Figure 4. The equilibrium level of branding moves from $b^{\prime}$ to $b^{\prime \prime}$. Access to more inexpensive sources of productive labor actual leads to an increase in the extent of branding in the more affluent consumer markets.

Figure 4.

Impact of an exogenous change in subcontracted labor costs on branding, demand, and prices.

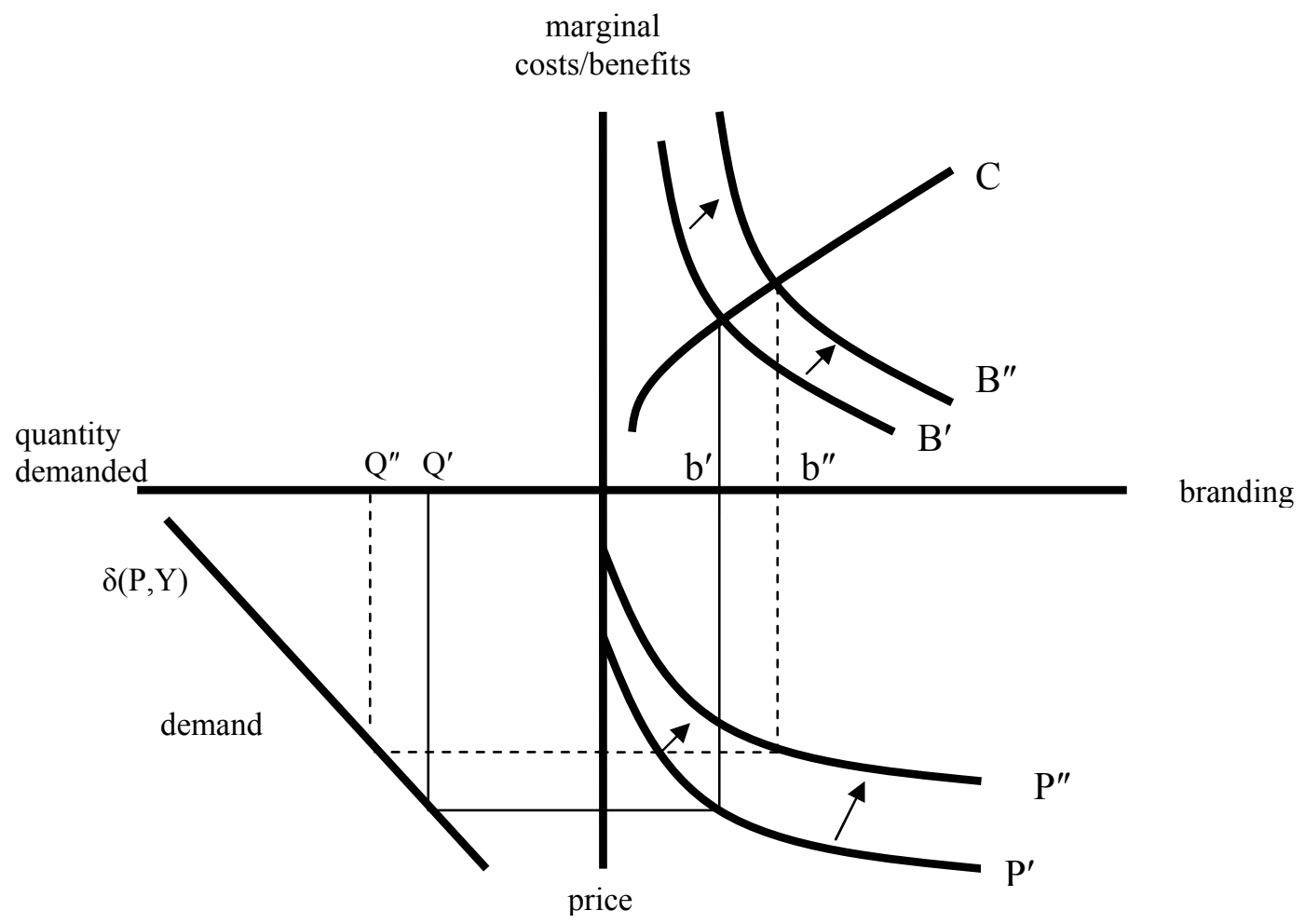

Why is this the case? Branding provides firms with monopoly rents and boosts their profitability. However, the extent of branding is constrained by the negative impact of higher prices on consumer demand. An exogenous change that makes cheaper sources 
of labor available will reduce retail prices for any given level of branding. After such a shift, the firm is no longer maximizing total rents at the original level of branding. Therefore, the retailer or brand-name producer can raise rents by extending their efforts at product differentiation and identity-building further. Before the reduction in labor costs, these higher levels of branding would have lowered total rents, since consumers would have reacted negatively to the price increases by reducing their demand.

This connection between globalized production and branding strategies is reflected in the actual strategic choices of multinational firms. For example, in 1999, the president of Levi-Strauss, John Ermatinger, justified the company's decision to switch to lower-cost subcontractors to produce the corporation's jeans in the following terms:

"Our strategic plan in North America is to focus intensely on brand management, marketing, and product design as a means to meet the casual clothing wants and needs of consumers. Shifting a significant portion of our manufacturing from the U.S. and Canadian markets to contractors throughout the world will give the company greater flexibility to allocate resources and capital to its brands." (Quoted in Klein 2002: 195)

The remaining parts of Figure 4 illustrate what happens to prices and demand when average labor costs decline. The lower right quadrant of Figure 4 shows the impact on prices. Since production costs are lower, the price curve shifts towards the horizontal axis. At a given level of branding, prices fall. However, this tendency for prices to fall is partially offset by the higher levels of branding. In Figure 4, the net effect is a reduction in prices which leads to an increase in demand, as seen in the lower left quadrant. Total rents increase due to a combination of higher per unit rents and increased demand.

The cost savings from access to lower-cost producers will not always be used to expand the branding of a company's products. Reducing consumer prices to boost overall demand is an alternative strategy. Higher levels of demand will raise total rents, even if the per unit benefits of branding remain unchanged. Whether a firm chooses to reduce retail prices or to expand its branding efforts depends on the elasticity of demand for the products it is selling. As final consumption demand for a product becomes more elastic, the indirect marginal costs of branding will rise more rapidly, and firms will be more likely to lower retail prices than increase branding. For example, discount retailers (e.g. Wal-Mart or Kmart), which sell brand-name products for which close substitutes are often available, will tend to increase their total rents by focusing on expanding their sales volume and keeping prices low. However, specialty retailers (e.g. The Gap, Nike, or Disney), which invest more in creating brand identities that limit the perceived substitutability of their products, are more likely to focus on developing their brands without lowering prices.

Changes in any of the parameters governing the distribution of value across the commodity chain will affect branding decisions and competitive strategies. The relevant comparative static calculations are contained in Appendix A. Table 1 summarizes these results for total rents and the branding variable. Note the impact on retail prices is more 
complex. In general, any exogenous change that lowers production costs or reduces the share of intermediaries will lower retail prices. However, this need not be the case. Under certain circumstances - the existence of an inelastic demand curve and high marginal rents due to branding - lower production costs can actually lead to higher retail prices in this model. This occurs when the increase in per unit rents associated with a higher level of branding more then off-set the effect of lower production costs.

Table 1

Comparative statics of commodity chain model

\begin{tabular}{|l|c|c|}
\hline & $\begin{array}{c}\text { Branding } \\
(\mathbf{b})\end{array}$ & $\begin{array}{c}\text { Total rents } \\
\boldsymbol{\delta}(\mathbf{P}, \mathbf{Y}) \boldsymbol{\alpha}(\mathbf{b})\end{array}$ \\
\hline - real production wages & - & - \\
\hline$t$ - labor productivity & + & + \\
\hline$e$ - exchange rate (e.g. \$US/local) & - & - \\
\hline$r$ - intermediary share & - & - \\
\hline
\end{tabular}

Although the focus here has been on branding and globalized manufacturing, the model can be easily generalized to other forms of monopolistic rent-seeking. For example, many agricultural and horticultural products - e.g. coffee production - are tied into commodity chains which could be analyzed using the same general model. Likewise, the commodity chain involving computer products could be modeled using a similar technique. Relatively generic electronic component parts are assembled in globalized networks while the rents associated with software development tend to accrue in advanced economies. Branding plays some role in software markets, but the existence of network externalities (i.e. the value of a particular software program depends on how many other people are using it) and more traditional monopolistic behavior also characterizes the industry.

How does this analysis fit into the earlier literature on unequal exchange and global inequalities? If subcontractors and production workers face highly competitive conditions, in the long-run they will be unable to capture the direct benefits of technological improvements or productivity enhancements in terms of higher standards of living, either in terms of increased profits or higher wages. The distribution of productivity gains will depend on the optimal competitive behavior of the large multinationals that possess some degree of monopoly power. Depending on the nature of the specific consumer market, the gains from low-cost production will be distributed between affluent consumers on the one hand and brand-name multinationals on the other. Bhattacharya and Rahman (1999) provide some empirical evidence supporting this argument. Their study of the export-oriented, female-dominated garment industry in Bangladesh shows that wages have not kept up with productivity increases. Instead, production costs have fallen, suggesting that some of the gains from productivity improvements are captured elsewhere along the commodity chain.

Innovative producers might be able to capture some short-run gains by raising productivity, cutting prices, and thereby increasing demand for their output. However, competitive pressures among other subcontractors to reduce their unit labor costs will 
erode these gains over time. Long-run incentives might be inadequate for a subcontractor to invest in productivity improvements. If the short-term benefits are not sufficient to cover the costs of investing in productivity improvements prior to the dynamic adjustment to a new low-cost equilibrium, these improvements will not be made. Under these conditions, export production tied to a global commodity chain would be characterized by a low-wage/low-productivity trap. ${ }^{17}$ Of course, when a new competitor with lower production costs enters the market, other producers have a clear incentive to improve productivity. However, the gains are realized in terms of retaining jobs and output, not in terms of higher average living standards per worker.

Despite the inability of subcontracted labor to capture the direct long-run benefits of productivity improvements in this model, the impact of the growth of export manufacturing in developing countries on the inequalities that exist between rich and poor nations is not obvious. The income generated by new jobs must be taken into account. Low-wage, export-oriented manufacturers can raise aggregate incomes in developing nations when growth in consumption expenditures generates additional employment opportunities in low-wage manufacturing. Higher levels of employment raise the total income of wage earners and could potentially narrow the gap between rich and poor. However, there is no guarantee that growing consumerism in wealthy nations will produce large numbers of good jobs in the developing world. It is to this issue that I now turn.

\section{Consumer demand, employment, and wages}

Can growth in real demand in the consumer markets of high-income nations generate a large number of new employment opportunities in the developing world and will such job creation help reduce global inequalities? Given the possibility that productivity-led expansions in the export sectors of developing countries might be constrained in their ability to raise employment incomes, this is a particularly relevant question for understanding the role that demand-led employment creation could play as part of a broader development strategy.

Some economists, such as Jeffrey Sachs and Paul Krugman, have argued that, even at poverty wages, sweatshops and low-wage workplaces are a move towards more egalitarian outcomes (Krugman 1998, Myerson 1997). Their logic is straight-forward: new manufacturing jobs offer a higher income for workers in developing countries than do alternative economic activities. This emphasis on employment must be taken seriously. The International Labor Organization estimates that at the end of 2002, approximately 180 million people will be unemployed around the world (ILO 2003). Even China, a champion of low-wage production for the global market, is facing a burgeoning problem of unemployment (Xuejin 2000). However, the argument that the proliferation of extremely low-wage, export-oriented jobs is an egalitarian force in the

17 Preliminary empirical estimates by Seguino (2003) suggest that higher levels of capital mobility reduce productivity growth. Although Seguino focuses on foreign direct investment and capital mobility instead of commodity chains and subcontracting, her work provides some evidence that supports the idea of a lowwage/low-productivity trap along the lines described here. 
global economy is not a foregone conclusion. Whether the consumption gap between rich and poor countries can be narrowed depends, in part, on the responsiveness of employment creation to growth in output and global demand.

In order to keep the arguments clear, I will limit this initial discussion to a simple context in which low-wage export manufacturers in the developing world produce goods exclusively for consumption in the relatively affluent markets of the global North. Therefore, the primary comparison will be between the income/consumption of manufacturing workers in the global South and consumers in the global North. Extending the analysis of branding and commodity chains developed in the previous section, the focus is on the relationship between the export-oriented manufacturing sectors of developing countries, taken together, and consumption abroad. In particular, expansion of output in the export sectors is assumed to be led by consumer demand in high-income markets. In this respect, the scenario is that of a demand-driven commodity chain.

For the time being, I will restrict my analysis to the impact of changes in consumer demand in high-income countries on the total wage income received by workers who participate in the labor market for export-sector manufacturing. This includes currently employed workers, both formal and informal, unemployed individuals, and people working in subsistence activities who would accept a manufacturing job if one were to become available.

Given these assumptions, what would be the impact of an exogenous increase in consumer demand from high-income countries on the total wage income of export workers? Labor demand is derived from demand for imports and is a function of real wages. This is simply a reformulation of the unit labor cost term in the model developed in the previous section. ${ }^{18}$ Therefore, total real wage income, I, is given by

(6) $I=w_{r} N\left(w_{r}, \delta(P, Y)\right)$

in which $\mathrm{w}_{\mathrm{r}}$ is the real manufacturing wage per employee, $\mathrm{N}$ is total employment in the sector, and $\delta$ represents demand for imported consumer goods as a function of price and income in the affluent consumer markets.

Expressed as percent changes, the impact of changes in wages and demand for exports on employment income is:

$$
\text { (7) } \frac{d I}{I}=(1+\eta) \frac{d w_{r}}{w_{r}}+\varepsilon\left(\rho \frac{d P}{P}+\chi \frac{d Y}{Y}\right)
$$

18 Total employment in the export sector is simply demand for output divided by labor productivity. If labor productivity is a function of technological changes and workplace organization influenced by exogenously given factor prices - in this case, the real wage rate - then we can write labor demand as a function of output demand and wages. 
where:

$\eta$ represents the wage elasticity of employment;

$\varepsilon$ represents the elasticity of employment with respect to output/demand;

$\rho$ represents the price elasticity of import demand;

and $\chi$ represents the income elasticity of import demand.

If we limit our attention to price changes associated with wage fluctuations at the point of production, Equation (7) could be expressed as:

(8) $\frac{d I}{I}=\left(1+\eta+\varepsilon \rho \frac{d P / P}{d w_{r} / w_{r}}\right) \frac{d w_{r}}{w_{r}}+\varepsilon \chi \frac{d Y}{Y}$

However, in a labor-surplus economy, the number of workers willing to accept a job greatly exceeds the number of available employment opportunities. In a competitive market with a surplus of labor, we can assume that the growth in jobs would not bid up wages. Under such conditions, we can greatly simplify the above relationship:

$$
\text { (9) } \frac{d I}{I}=\varepsilon \chi \frac{d Y}{Y}
$$

That is, changes in wage income in the export sector depends on income growth in the consumer markets, the elasticity of employment with respect to output, and the income elasticity of import demand. This simplifying assumption of constant, competitive wages will be relaxed later.

As described earlier, the income elasticity of demand for goods exported from developing countries and imported by more advanced economies is an important variable in the unequal exchange tradition, particularly in the work of Prebisch and Singer. The demand for raw materials and primary products was assumed to be income and price inelastic. However, the same argument might not apply to manufacturing exports from developing countries. Growth in the consumer economies of the global North could result in even faster growth of wage income in export sectors of the global South if import demand turns out to be income elastic. Under such conditions, the expansion of buyerdriven commodity chains associated with the new international division of labor would contribute to greater income equality between low-wage export workers and high-income consumers, all other factors being equal.

Estimates of the income elasticity of import demand in the U.S. and other industrialized countries generally lie between 1.0 and 3.0 (Deyak, Sawyer, and Sprinkle 1997, Senhadji 1997, Goldstein and Khan 1985). That is, import demand appears to be elastic. However, these estimates might not apply to import demand for manufactured consumer goods that typically are produced and exchanged along demand-driven commodity chains. 
To gauge the magnitude of the income elasticity of demand for these imports, I estimated a set of relationships for the United States in which demand is a function of the relative price of imports and real personal disposable income. Data on imports of real manufactured consumer goods, excluding automobiles, were taken from the U.S. Bureau of Economic Analysis. Import prices for non-automobile consumer goods came from the price indices of the Bureau of Labor Statistics. Relative import prices were calculated as a ratio of the import price index and the consumer price index (CPI) for non-food, nonenergy consumer goods. Finally, real income is measured as personal disposable income, deflated by the consumer price index. The time series is quarterly and runs from 1982:2 to $2002: 1$.

Details of the estimation procedure are contained in Appendix B. Estimates of both the short-run and the long-run price and income elasticities were generated and are summarized in Table 2 below. The long-run income elasticity of import demand for manufactured consumer goods in the U.S. is estimated to be 2.64 - that is, import demand is income elastic and its magnitude is in line with similar estimates of income elasticities. When import demand is highly responsive to positive changes in income, the long-run expansion of consumer economies, like that of the United States, results in a proportionately more rapid growth of demand for consumer imports. This implies that total wage income of export producers in demand-driven commodity chains would increase at a faster rate than incomes in the more affluent consumer markets (see Equation 9). This is a notable difference with the earlier work in the unequal exchange tradition which focused on developing countries specialized in producing raw materials and primary commodities. However, it is consistent with the empirical studies reviewed earlier that describe declining or trendless commodity terms of trade and raising income terms of trade.

Table 2

Import demand elasticities - summary of estimates

\begin{tabular}{|l|c|c|}
\hline & Short-run & Long-run \\
\hline Price & -0.61 & -2.92 \\
\hline Income & 0.63 & 2.64 \\
\hline
\end{tabular}

Source: See Appendix B for details.

What do these results imply in terms of the question of divergent growth? When total wage income of export producers increases at a faster rate than incomes in affluent consumer markets, we would expect relative income inequality between these groups to decline, as measured, for example, by the ratio of consumer income to the employment income in low-wage manufacturing. ${ }^{19}$ This implies that increased manufacturing production in low-wage export sectors would contribute to convergent growth or, at least, reduce the rate of divergence. This effect will be larger if exports constitute a large share of total production or if there are strong multiplier effects associated with an expansion of net exports. If exports are relatively unimportant or multiplier effects are small, the

19 This argument holds for income per capita if the relevant population growth rates are identical. 
contribution to convergence would be reduced. In addition, absolute differences in income could widen, at least initially, even if relative inequality falls.

The income elasticity of demand is not the only factor influencing the responsiveness of employment income to demand growth. There is another variable in Equation 9 that must be considered - the elasticity of employment with respect to output. The magnitude of this variable will be related to how technological changes and workplace organization affect labor productivity. If labor productivity were held constant, we would expect the employment elasticity of output to be equal to one. That is, a doubling of output would require a doubling of the labor input. However, if labor productivity increases with an expansion of output, due to better technologies, more capital investment, higher rates of capacity utilization, or changes in production processes, then an increase in output would require a proportionately smaller increase in labor. $^{20}$

Take the example of a highly globalized, labor-intensive sector: the international apparel industry. Using data from the United Nations Industrial Development Organization (UNIDO) and the World Bank, the long-run elasticity of employment with respect to output were estimated using a panel data set covering 49 countries from 1981 to 1996. Details of these estimations are contained in Appendix C of this paper. The longrun elasticity was estimated to be 0.86 - that is, a 10 percent increase in output is associated with an 8.6 percent increase in employment. Although close to one, this result suggests that labor productivity tends to increase as output expands, reducing the jobcreation potential of demand growth in consumer markets. For products other than clothing, for which the adoption of labor-saving technology might be easier, this elasticity would be expected to be lower.

This relationship between labor productivity and employment implies a particular dynamic for wage incomes of export workers in a global commodity chain.

Technological changes that raise labor productivity could actually reduce wage incomes in developing countries if growth in employment opportunities were curtailed as a result. As pointed out earlier, competitive pressures at the point of production limit the extent to which such gains could be retained as higher wage incomes or larger profit shares in the export industries themselves. However, there is a countervailing trend. If productivity improvements lower consumer prices, demand for exports would expand and more employment would be created at the prevailing wage. Whether productivity improvements raise employment incomes depends on whether the effect of lower prices can off-set the labor-displacing effect of higher productivity.

The estimates presented earlier suggest that demand for manufactured consumer imports is price elastic. Therefore, the demand effects will outweigh the displacement effects if changes in prices are proportionate to changes in unit labor costs. ${ }^{21}$ However, if

20 Growth in employment opportunities often falls below output growth. See, for example, UNDP(1996) and Streeten (1994).

${ }_{21}$ That is, a 10 percent increase in productivity should result in a 10 percent decrease in employment and unit labor costs if output and wages are held constant. However, if prices decline proportionately to unit 
a significant portion of the productivity improvements are captured as higher rents, not lower prices, elsewhere along the commodity chain, then the effect on total employment income will be negative.

Along similar lines, suppose we relax the initial, simplifying assumption that highly competitive conditions in labor surplus economies prevent real wages from increasing as output expands. Instead, wages are allowed to rise modestly with an expansion in output and employment. Under these more forgiving conditions, would higher average wages help boost the expansion of the employment income of manufacturing workers in developing countries? The answer is not obvious and again depends on how responsive labor and import demand are to wage increases. If both import and labor demand are sensitive to changes in labor costs, then higher wages will reduce employment and lower the total income workers receive. Returning to Equation 8, the impact of a wage increase on total income from employment can be separated into two effects: (1) a labor demand effect at the level of production and (2) a price effect at the level of consumption. The relative size of these distinct influences on employment income will determine whether higher wages will help or hurt individuals working in export manufacturing.

If we focus only on the labor demand effect, higher wages will lower total income when the wage elasticity of employment falls below -1 (that is, the absolute value is greater than 1). An empirical estimation of labor demand relationships for the global apparel industry - a labor-intensive export sector - produces wage elasticity estimates of -0.61 (see Appendix B for the estimation details). Therefore, in the global apparel sector higher wages will raise total employment income if output prices do not change.

However, higher labor costs will likely raise prices. Furthermore, the U.S. import demand estimations of Table 2 show that import demand is price elastic. Although higher wages might have a positive impact on total employment income at the point of production, even in labor-intensive sectors such as apparel, this gain could be countered by a pricesensitive decline in import demand. ${ }^{22}$

The magnitude of this price effect depends on how prices respond to wage increases. Even in labor-intensive industries such as footwear and apparel, labor costs do not account for an overwhelming share of the retail price of imports (see, for example, Pollin, Burns, and Heintz 2001). Therefore, relatively large wage increases can result in substantially smaller percent changes in retail prices. Moreover, there is evidence that consumers are willing to pay more for goods that they know are produced under decent employment conditions (Eliott and Freeman 2000). Certification and labeling schemes could give these products a competitive advantage in consumer markets relative to

labor costs, demand will increase by more than 10 percent when the absolute value of the price elasticity of demand exceeds one. Adding these two effects together yields positive employment growth.

22 As one would expect, estimates of demand elasticities for imports coming from a particular country tend to be much higher than for aggregate imports, although there is much empirical debate over this issue. For example, see Panagariya, Shah, and Mishra (2001). Under these conditions, a country or export sector, acting alone, would face much stronger negative price effects than would be the case if all exporting countries raised wages simultaneously. This latter situation could result from the adoption of an internationally coordinated set of labor standards. 
otherwise identical goods. Under these conditions, higher prices could actually result in an expansion of demand (Conroy 2001) - since very similar products may no longer be viewed as close substitutes. In general, whether higher wages will reduce employment through import price effects will depend on how sensitive prices are to wages and whether better wages are connected to other adjustments, such as product differentiation and the creation of niche markets.

\section{Discussion}

When import demand is sufficiently income elastic, the growth of consumer markets in the global North contributes to the reduction of inter-country inequalities through the creation of new economic opportunities that raise aggregate employment income among export workers, all other things equal. In terms of reducing income inequalities, a demand-led expansion can be superior to productivity improvements which do not raise, and may actually reduce, long-run employment incomes. This is likely to be the case when the gains from productivity improvements are captured as higher rents, instead of lower prices, elsewhere in the commodity chain. Despite the arguments presented to this point, there are serious problems with viewing the demandled growth of commodity chains, as they are currently constituted, as a sustainable force for egalitarian employment-led development.

First, wages can be lowered by tapping more vulnerable segments of the labor market - workers who have a weaker employment bargaining position due to limited access to alternative income sources. For example, global commodity chains have been extended into the informal economy and many global production networks have incorporated home-based workers (Carr, Chen, and Tate 2000). The expansion of such relationships lowers average wages and could reduce employment income even when aggregate demand is growing. Under these conditions, income terms of trade will fall as output expands unless social protections are extended to these new employment relationships.

The reduction of export sector wages is a highly gendered phenomenon. The decline in average job quality that accompanied the growth in women's labor force participation has been termed "global feminization" (Standing 1989). However, it is also important to recognize that, since labor markets remain segregated by gender, the growth in women's share of low-wage employment also results from an expansion of jobs typically dominated by women (Elson 1996). Such segmentation can undermine women's bargaining power with respect to paid employment. Since women are often employed in globally mobile industries, an expansion of employment in these sectors may not raise women's bargaining power relative to men working in less footloose sectors (Seguino 2002). These gender dynamics could cause total employment income to decline. However, it is important to be cautious in drawing conclusions about the welfare implications of a fall in employment income. Access to money income improves women's bargaining position at home, thereby strengthening women's influence over the 
distribution of household resources - with potentially positive welfare implications for themselves and their children (Braunstein 2002, Sen 1990, Roldan 1988, Joekes 1987). ${ }^{23}$

Second, a direct link to the fortunes of affluent consumer economies is a curse as well as a blessing. When consumer incomes are growing, demand for manufactured consumer imports outpaces the growth of income and employment expands in low-wage export sectors. However, downturns will produce the opposite effect. Growth and incomes will co-vary in economies integrated through global commodity chains. Increasingly globalized business cycles produce more serious fluctuations in employment and income due to cross-border feedback effects.

Third, there is the question of macroeconomic sustainability. Imports cannot continue to grow faster than income in the advanced economies without eventually creating a balance of payments problem due to expanding trade deficits, unless exports also grow at a similar rate. If exchanges rates adjust to reduce this gap, then import demand will fall due to rising prices. A country, like the U.S., with a strong hegemonic currency in international financial markets, could potentially finance an on-going trade deficit without an exchange rate correction that would drastically cut imports. Indeed, the U.S. has maintained a trade deficit for decades. However, it is unclear by how much trade deficits in advanced economies can continue to expand until they become unsustainable.

A fourth concern is that competition among emerging industrial sectors to secure greater export market share can lead to overcapacity when growth of production outstrips the growth of global demand (Erturk 2002). Such excess capacity will place downward pressure on prices and production costs, thereby further limiting the ability of producers and workers to capture the value generated along global commodity chains. Slower global growth and the inability to sustain increasing import demand in the industrialized North exacerbate this dynamic.

Fifth, environmental sustainability must be taken into consideration when the growth of employment income in developing economies is predicated on an increase in incomes and consumption in the global North. This is particularly important since the expansion of import demand discussed here is a component of the overall growth in consumption, not a targeted increase in import demand alone. Annual consumption in the world's advanced economies currently devours a significant quantity of material resources. For example, a study of selected advanced economies found that to generate $\$ 100$ of income in Germany, the Netherlands, or the United States requires about 300 kilograms of natural resources (Adriaanse et al. 1997). This translates into a requirement of 75 to 85 metric tons of material resources to support the annual consumption of a typical person in these economies. Pursuing development strategies that explicitly link higher incomes in poor countries to a continuous expansion of current patterns of

23 This increase in household bargaining power can depend on the size and constancy of income flows. For example, Naila Kabeer (2000) demonstrates these complexities in her study comparing the impact of participation in remunerative work on household bargaining dynamics for women in Dhaka, Bangladesh, who worked in factory jobs, relative to female Bangladeshi immigrants in London, who often were employed in home-working situations. 
consumption in high-income nations will likely have serious environmental consequences in the future.

Finally, it is important to keep in mind that, although growth in consumer demand creates new employment opportunities, these are low-wage jobs. In many cases, production takes place in the informal economy, in unregulated factories, or in homebased work with few, if any, social protections. Indeed, access to paid employment is frequently insufficient to raise a household above a basic dollar-a-day poverty threshold (Majid 2001). As mentioned earlier, a low-productivity, low-wage trap is possible in which the proliferation of poverty-level jobs is only desirable because of the wretchedness of the next-best options.

These cautionary observations are not meant as a call to dismantle demand-driven commodity chains, but rather as an argument for transforming the way they operate and the way market power is distributed. The growth potential of global production networks is strong and need not be limited to low-wage employment creation through the expansion of derived demand. Furthermore, transforming global production and distribution systems can support on-going development objectives in ways that a lowproductivity, low-wage equilibrium growth path cannot.

In this discussion, I will briefly look at four redistributive strategies for transforming the current structure of buyer-driven commodity chains that do not necessarily depend on the growth of income and consumption in affluent consumer markets. These are: (1) asymmetric trade liberalization in the global North; (2) industrial up-grading; (3) the implementation of codes of conduct and global labor standards; and (4) fostering the development of domestic markets and South-South commodity chains.

Asymmetric trade liberalization in the global North. This policy intervention has received a great deal of attention in recent years, often focusing on on-going trade negotiations, such as the dismantling of the Multi-Fiber Arrangement (MFA), debates over agricultural subsidies, and agreements on non-agricultural market access (NAMA). Traditional trade barriers, non-tariff barriers, and production subsidies in the world's advanced economies all restrict access to high-income consumer markets. Often, laborintensive goods are relatively more highly protected than capital-intensive goods (UNCTAD 2002). Removing these barriers to trade redistributes income to poorer countries, creating new employment opportunities. Such reforms produce one-shot redistributions, but the growth in income could have long-run dynamic effects. Nevertheless, this strategy does not address the deeper structural problems identified by the unequal exchange tradition. Therefore, such trade reforms need not be symmetric. That is, developing economies could retain certain protections that form part of a larger industrial policy. As per capita incomes rise, the extent of these protections would be reduced.

Industrial up-grading. Industrial up-grading refers to the movement up global commodity chains in order to capture a larger share of the income and rents generated through the process of production and distribution (Gereffi 1999, Kaplinsky 1998). In 
particular, if producers in the lower echelons of global commodity chains are able to share in the various types of rents generated at other points, this provides the resources needed to raise average incomes and to move towards creating more decent employment opportunities (Kaplinksy 1998). ${ }^{24}$ The success of the four original "Asian tigers" (Taiwan, South Korea, Hong Kong, and Singapore) is often cited as an example of the potential of industrial up-grading. ${ }^{25}$ These economies moved from assembling goods for Western consumer markets to producing higher value-added exports and, in some cases, creating their own brand identities.

However, there are problems with assuming that industrial up-grading will be an automatic outcome of the growth of global production networks. In the case of the "Asian tigers", industrial up-grading was accompanied by the out-sourcing of assembly and basic manufacturing functions to lower wage countries in Asia and Central America. ${ }^{26}$ In these cases, industrial up-grading represented a displacement, rather than a transformation, of low-wage, low-productivity production. In addition, current competitive pressures might constrain the capacity for up-grading of the new generation of low-wage exporters by limiting the resources and the flexibility needed for pursuing long-run strategies of industrial development. Furthermore, as more and more countries compete on the global export market, the opportunities for additional export penetration could be curtailed (Erturk 2002). The four original Asian tigers were able to successfully up-graded their industries because of their industrial policies and the existence of extensive governmentindustry linkages; these strategies might not be available to all countries. Such a situation creates the possibility of a two-tiered growth path for developing economies, in which the poorest and most underdeveloped face continued marginalization.

Codes of conduct and global labor standards. The enforcement of international labor standards by certifying compliance with a code of conduct also has potential for raising employment incomes at the level of production. However, care must be taken with implementation. Since subcontractors face intense competition, pushing these firms to raise wages and labor standards and absorb the higher costs is likely to produce unintended consequences, such as job losses. Nevertheless, brand-name manufacturers and large retailers possess the market power needed to implement improvements in labor standards at the level of production by compensating subcontractors for the cost

24 In the apparel industry, industrial up-grading often consists of moving from "cut, make, and trim" (CMT) operations, in which the cloth is supplied by the contracting firm, to "full-package" (FOB) exporting, in which the subcontractor is entirely responsible for manufacturing ready-to-wear clothing. With full-package exporting, the brand-name company effectively withdraws from the production process. When subcontractors provide these additional services, they can claim a larger share of the income generated throughout a commodity chain.

25 The industrial development of East Asian economies has sometimes been described as following a "wild-geese-flying" pattern, a term coined by Kaname Akamatsu (1962). According to this theory, international linkages allow less-developed economies to up-grade their industries by following the economic development of more advanced economies as they proceed through various stages of development.

26 The exact extent to which such outsourcing was caused by a search for low-wage production to support industrial up-grading is difficult to ascertain since this geographical dispersion also involved "quotahopping" - that is, moving production to new countries in order to avoid the quota restrictions imposed by the Multi-Fiber Arrangement. 
increases. For example, they could raise retail prices modestly and pass these revenues back to finance the improvements in employment conditions. As previously mentioned, studies have found that consumers are willing to pay a price premium for products produced under decent working conditions. Therefore, unintended job losses would be avoided since subcontractors who complied with the standards would receive the resources necessary to implement the improvements without reducing the final demand for the products.

The creation, implementation, and enforcement of codes of conduct are components of another strategy for redistributing rents across global commodity chains. Because of the rents associated with branding, retailers and brand-name manufacturers are sensitive to reputation effects that might damage a carefully crafted corporate image. A bad image can be disastrous for profits and can cripple a company's ability to secure future branding rents. This vulnerability can be leveraged in order to redistribute resources across the commodity chain to subcontracted workers. In many respects, the implementation of a code of conduct represents a variation on the more general strategy of changing the distribution of rents across commodity chains. However, unlike industrial upgrading and similar innovations, codes of conduct target the large multinationals that possess most of the market power within a commodity chain.

Domestic markets and South-South commodity chains. The limitations of a purely export-oriented employment strategy to improve relative living standards raise a more profound question - are there alternative approaches to employment-led development that would be appropriate as part of a more comprehensive set of economic policies? The disjuncture between domestic markets and domestic production in the current pattern of globalization makes the logic of an export-oriented strategy seem compelling. However, a different possibility would be to pursue policies that reconnect production with domestic needs and demands. Such a program would differ from strict stabilization packages aimed at achieving external balances. For example, the strategy would need to regulate financial flows and capital mobility in order to create space for more autonomous state interventions in industrial policy and development. Furthermore, instead of arbitrary fiscal deficit targets, it could emphasize public investments in infrastructure. The policies would not have to be insular or protectionist. Instead, the emphasis would be on pursuing interventionist strategies to regulate global markets and meet domestic objectives.

Along these same lines, an emphasis on the expansion of South-South trade, pursued with domestic development strategies, could help close the gap between rich and poor nations by limiting the dependence of manufacturing exports from low-income countries on the expansion of affluent consumer markets. Instead, the expansion of consumption in developing nations would support the expansion of South-South trade with rents remaining in developing countries. The fact that economic linkages are forged between developing countries does not preclude an unequal distribution of opportunities or a race to the bottom. Indeed, South-South competition can often be fiercer than NorthSouth competition. However, an emphasis on a cooperative approach to developing 
domestic markets along with expanding export capacity would limit the possibility of destructive outcomes arising from intense competition.

\section{Conclusions and future research}

This paper has argued that the expansion of manufacturing exports from developing economies contributes to a more equal distribution of income when demand for consumer imports responds vigorously to the growth of high-income consumer markets. The expansion of employment opportunities associated with growth in manufacturing production is the key factor behind rising employment incomes in developing countries. However, convergent growth conditioned on ever-increasing export consumption will likely prove to be unsustainable in the long-run due to macroeconomic constraints, environmental stress, or high levels of demand volatility. Furthermore, the competitive logic of globalized production can erode income gains when producers tap into more vulnerable segments of the labor market by employing workers with weaker bargaining positions.

The backdrop to this analysis has been the structure of global commodity chains. These institutional features impact the distribution of the net economic gains associated with an expansion of globalized manufacturing. Although the institutional environment has changed, the factors identified by theorists in the unequal exchange tradition remain relevant to understanding the power dynamics of today's production networks: market power is concentrated among firms in the advanced economies, sourcing decisions are characterized by a high capacity for international substitution from one producer to the next (creating a similar environment as would a high degree of capital mobility), producers in low-wage export sectors face extremely competitive conditions, and labor markets in developing countries are characterized by the existence of surplus labor.

This paper has explored a few of the distributive issues associated with low-wage manufacturing in developing countries. However, many questions remain. The model of global commodity chains could be adapted and more fully exploited to examine how changes in institutional relationships affect distributive outcomes. There is a need to disaggregate the empirical work presented here and to look more closely at sectoral and regional differences. In this same spirit, more country-specific studies would complement other research in shedding light on distributive issues, including employment, wage, and income relationships in export-oriented industries. Similarly, empirically-grounded microeconomic studies of the distributive dynamics of global commodity chains and how

they differ across industries would test the validity of many of the assumptions adopted in the theoretical models developed here. 


\section{Sources}

Abernathy, Fredrick, John Dunlop, Janice Hammond, and David Weil (1999), A Stitch in Time: Lean retailing and the transformation of manufacturing. Oxford, UK: Oxford University Press.

Adriaanse, Albert, Stefan Bringezu, Allen Hammond, Yuichi Moriguchi, Eric Rodenburg, Donald Rogich, and Helmut Schütz (1997), Resource Flows: the material basis of industrial economies, Washington, DC: World Resources Institute.

Aglietta, Michel (1979), A Theory of Capitalist Regulation. London: NLB.

Akamatsu, Kaname (1962) "A historical pattern of economic growth in developing countries," The Developing Economies 1(1): 3-25.

Arndt, Sven and Kierzkowski, Henryk, eds. (2001), Fragmentation: new production patterns in the world economy, Oxford, UK: Oxford University Press.

Athukorala, Premachandra (2000), "Manufactured exports and terms of trade of developing countries: evidence from Sri Lanka," Journal of Development Studies, 36(5): 89-104.

(1993), "Manufactured exports from developing countries and their terms of trade: a reexamination of the Sarkar-Singer results," World Development, 21(10): 1607-1613.

Bacha, Edmar (1978), "An interpretation of unequal exchange: from Prebisch-Singer to Emmanuel," Journal of Development Economics, 5: 319-330.

Bhagwati, Jagdish (1952), "Immiserating growth: a geometrical note," Review of Economic Studies, 25(3): 201-205.

Bhattacharya, Debapriya and Mustafizur Rahman (1999), "Female employment under export propelled industrialization: prospects for internalizing global opportunities in the apparel sector in Bangladesh," United Nations Research Institute for Social Development (UNRISD), Occasional Paper no. 10.

Braunstein, Elissa (2002), "Gender, FDI, and women's autonomy: a research note on empirical analysis," Political Economy Research Institute (PERI), University of Massachusetts, Working Paper 49.

Bonacich, Edna and Richard Appelbaum (2000), Behind the Label: inequality in the Los Angeles apparel industry, Berkeley, CA: University of California Press.

Boyer, Robert and Michel Julliard (2002), “The United States: Good-bye, Fordism!” In R. Boyer and Y. Saillard, eds., C. Shread, trans., Régulation Theory: the state of the art, London and New York: Routledge, pp. 238-46, (published originally in French, 1995).

Bowles, Samuel and Robert Boyer (1995), "Wages, aggregate demand, and employment in an open economy: an empirical investigation," in G. Epstein and H. Gintis, eds. Macroeconomic Policy After the Conservative Era, Cambridge, UK: Cambridge University Press, pp. 143-71.

Carr, Marilyn, Martha Chen, and Jane Tate (2000), "Globalization and home-based workers," Feminist Economics 6(3): 123-42.

Conroy, Michael (2001), "Can advocacy-led certification systems transform global corporate practices: evidence and some theory," Political Economy Research Institute (PERI), University of Massachusetts, Working Paper 21.

Deyak, Timothy, Charles Sawyer, and Richard Sprinkle (1997), "Changes in the income and price elasticities of U.S. import demand," Economia Internazionale, 50(2): 161-175.

Elliot, Kimberly and Richard Freeman (2000) "White hats or Don Quixotes? Human rights vigilantes in the global economy," National Bureau of Economic Research Conference on Emerging Labor Market Institutions, http://www.nber.org/ confer/2000/si2000/elliot.pdf.

Elson, Diane (1996), "Appraising recent developments in the world market for nimble fingers," In A. Chhachhi and R. Pittin, eds. Confronting State, Capital, and Patriarchy: women organizing in the process of industrialization, New York: St. Martin's Press, pp. 35-55.

Emmanuel, Arghiri (1972), Unequal Exchange: a study of the imperialism of trade, New York and London: Monthly Review Press.

Erturk, Korkut (2002), "Overcapacity and the East Asian crisis," Journal of Post-Keynesian Economics, 24(2): 253-75

Ford, Henry (1973), My Life and Work. New York: Arno Press.

Fussell, Elisabeth (2000), "Making labor flexible: the recomposition of Tijuana's maquiladora female labor force." Feminist Economics. 6(3): 59-80. 
Gereffi, Gary (1999), "International trade and industrial up-grading in the apparel commodity chain," Journal of International Economics, 48(1): 37-70.

(1994), "The organization of buyer-driven global commodity chains: how U.S. retailers shape overseas production networks." In G. Gereffi and M. Korzeniewicz, eds. Commodity Chains and Global Capitalism. Westport, CT and London: Greenwood Press. pp. 95-122.

Glyn, Andrew, Alan Hughes, Alain Lipietz, and Ajit Singh. (1990). "The rise and fall of the Golden Age." In S. Marglin and J. Schor, eds. The Golden Age of Capitalism: Reinterpreting the Postwar Period. Oxford, UK: Clarendon Press.

Goldstein, Morris and Mohsin Khan (1985), "Income and price effects in foreign trade," in R. Jones and P. Kenen, eds., Handbook of International Economics, Vol. II, Amsterdam: Elsevier, pp. 1041-1105.

ILO (2003), Global Employment Trends, Geneva: International Labor Organization, pp. 2-10.

Henderson, Jeffrey, Peter Dicken, Martin Hess, Neil Coes, and Henry Wai-Chung Yeung, "Global production networks and the analysis of economic development," Review of International Political Economy, 9(3): 436-64.

Joekes, Susan (1987), Women in the World Economy, Oxford, UK: Oxford University Press.

Jones, Ronald (2000), Globalization and the Theory of Input Trade, Cambridge, MA: The MIT Press.

Kabeer, Naila (2000), The Power to Choose: Bangladeshi women and labor market decisions in London and Dhaka, London: Verso.

Kaplinsky, Raphael (2000), "Spreading the gains from globalization: what can be learned from value chain analysis?" Institute for Development Studies (IDS), University of Sussex, Working Paper 110. (1998), "Globalization, industrialization, and sustainable growth: the pursuit of the Nth rent," Institute for Development Studies (IDS), University of Sussex, Discussion paper 365.

Kennickell, Arthur, Martha Starr-McCluer, and Brian Surette (2000), "Recent changes in U.S. family finances: results from the 1998 Survey of Consumer Finances. Federal Reserve Bulletin, 86(January): 1-29.

Kennickell, Arthur and Martha Starr-McCluer (1994), "Changes in family finances from 1989 to 1992: evidence from the Survey of Consumer Finances. Federal Reserve Bulletin, 80(October): 861-82.

Klein, Naomi (2002), No Logo, New York: Picador Press.

Krugman, Paul (1998), The Accidental Theorist. New York: Norton.

Lewis, W. Arthur (1954), "Economic development with unlimited supplies of labor," Manchester School of Economic and Social Studies, 22(2): 139-91.

Maizels, Alf (2000), "The manufactures terms of trade of developing countries with the United States, 1981-97," Oxford University, Queen Elizabeth House, Working Paper Series QEHWPS36.

Majid, Nomaan (2001), "The working poor in developing countries," International Labour Review, 140(3): 271-91.

Medeiros, Carlos (2000), "High wage economy, Sloanism, and Fordism: the American experience during the Golden Age." Contributions to Political Economy 19: 33-52.

Minford, Patrick, Jonathan Riley, and Eric Nowell (1997), "Trade, technology, and labour markets in the world economy, 1970-90: a computable general equilibrium analysis," Journal of Development Studies, 34(2): 1-34.

Mishel, Lawrence, Jared Bernstein, and John Schmitt (2001), The State of Working America 2000-2001. Ithaca, NY: Cornell University Press.

Mokhtari , Manouchehr (1992), "An alternative model of U.S. clothing expenditures: application of cointegration techniques," Journal of Consumer Affairs, 26(2). 305-19.

Myerson, Allen (1997), "In principle, a case for more 'sweatshops"”. New York Times, June 22, p. E5.

Panagariya , Arvind, Shekhar Shah, and Deepak Mishra (2001), "Demand elasticities in international trade: are the really low?" Journal of Development Economics, 64: 313-342.

Piore, Michael and Charles Sabel (1984), The Second Industrial Divide: possibilities for prosperity, New York: Basic Books.

Pollin, Robert, Burns, Justine, and Heintz, James (2001), “Global Apparel Production and Sweatshop Labor: Can Raising Retail Prices Finance Living Wages?” Political Economy Research Institute (PERI), University of Massachusetts, Working Paper 19.

Prebisch, Raúl (1950), "The economic development of Latin America and its principal problems," United Nations Economic Commission for Latin America, 7(1) [Reprinted in (1962), Economic Bulletin for Latin America, 7(1), United Nations]. 
Raff, Daniel K.G. (1988), "Wage determination theory and the five-dollar day at Ford." Journal of Economic History. 48(2): 387-399.

Rodrik, Dani (1997), Has Globalization Gone Too Far? Washington, D.C.: Institute for International Economics.

Roldan, Martha (1988), "Renegotiating the marital contract: intrahousehold patterns of money allocation and women's subordination among domestic outworkers in Mexico City," In D. Dwyer and J. Bruce, eds. A House Divided: women and income in the Third World, Stanford, CA: Stanford University Press, pp.229-247.

Samuelson, Paul (1948), "International trade and the equalization of factor prices." Economic Journal 58(230): 163-84.

Sarkar, Prabirjit and Hans W. Singer (1991), "Manufactured exports of developing countries and their terms of trade since 1965," World Development, 19(4): 333-340.

Schor, Juliet (1992), The Overworked American. The unexpected decline of leisure. New York: Basic Books.

Seguino, Stephanie (2003), "Is More Mobility Good? Mobile capital and the low wage-low productivity trap," the issues for Asian SIEs," mimeo., University of Vermont, Department of Economics, March.

(2002), "Gender equality through labor standards and living wages: an exploration of the issues for Asian SIEs," mimeo., University of Vermont, Department of Economics, November.

Sen, Amartya (1990), "Gender and cooperative conflicts," In I. Tinker, ed. Persistent Inequalities: women and world development, Oxford, UK: Oxford University Press, pp. 123-49

Senhadji, Abdelhak (1997), "Time-series estimation of structural import demand equations: a cross-country analysis," IMF Working Paper WP/97/132, International Monetary Fund.

Singer, Hans W. (1950), "The distribution of gains between investing and borrowing countries," American Economic Review, 40(2): 473-85.

Standing, Guy (1989), "Global feminization through flexible labor," World Development, 17(7): 1077-95.

Streeten, Paul (1994), Strategies for Human Development. Global poverty and unemployment. Copenhagen: Handelshøjskolens Forlag.

UNCTAD (2002), Trade and Development Report 2002, Geneva: UNCTAD.

UNDP (1996), "Translating growth into employment opportunities." Human Development Report. New York and Oxford: Oxford University Press. pp. 86-105.

U.S. Census Bureau (2000), Money Income in the United States 1999. Current Population Report P60-209. Washington, D.C.

Wood, Adrian (1997), "Opennes and wage inequality in developing countries: the Latin American challenge to East Asian conventional wisdom," The World Bank Economic Review, 11(1): 33-57.

Xuejin, Zuo (2000), "China's rural and urban employment in the reform era: recent trends and policy issues," In Peng Xizhe with Guo Zhigang, eds. The Changing Population of China. Oxford: Blackwell. 


\section{Appendix A}

\section{A.1. First and second order conditions.}

A firm chooses $\mathrm{b}$ to maximize total rents as given by the following objective function, presented as Equation 3 in the main text:

$$
\max _{b} \alpha(b) \delta(P, Y)-c \delta(P, Y)-\mu(b)
$$

The first order condition is:

$$
\alpha_{b} \delta(P, Y)+(\alpha-c) \delta_{P}\left(\frac{\alpha_{b}}{1-r}\right)-\mu_{b}=0
$$

The second order condition, which will be labeled S, is given by:

$$
S=\alpha_{b b}\left[\delta(P, Y)+\frac{\alpha-c}{1-r} \delta_{P}\right]+2 \delta_{P} \frac{\alpha_{b}^{2}}{1-r}+\delta_{P P}(\alpha-c)\left(\frac{\alpha_{b}}{1-r}\right)^{2}-\mu_{b b}<0
$$

The first two terms in the above expression are negative, given a downward sloping demand curve, decreasing marginal rents due to branding, and the first order condition. Likewise, the final term is negative if the marginal costs of branding are increasing. If we make a further assumption that $\delta_{\mathrm{PP}} \leq 0$, then the second order condition always holds. Note this assumption is consistent with a range of demand functions - including linear forms.

\section{A.2. Marginal benefit and cost curves.}

From the first order condition, we can derive an expression for the net marginal benefits of branding:

$$
B^{\prime}=\alpha_{b} \delta(P, Y)-\mu_{b}
$$

and the indirect marginal costs:

$$
C^{\prime}=-(\alpha-c) \delta_{P}\left(\frac{\alpha_{b}}{1-r}\right)
$$

Clearly $B^{\prime}$ is a decreasing function of $\mathrm{b}$, assuming decreasing marginal returns and increasing, or constant, marginal costs to branding: 


$$
\frac{d B^{\prime}}{d b}=\frac{\alpha_{b}^{2} \delta_{P}}{1-r}+\alpha_{b b} \delta(P, Y)-\mu_{b b}<0
$$

The shape of the marginal cost curve is more complex. Assuming the second order conditions hold as described above, marginal costs will be a convex function of $b$ with a positive slope over the relevant range for maximization:

$$
\frac{d C^{\prime}}{d b}=-\frac{\delta_{P}}{1-r}\left[\alpha_{b b}(\alpha-c)+\alpha_{b}^{2}\right]-(\alpha-c) \delta_{P P}\left(\frac{\alpha_{b}}{1-r}\right)^{2}>0
$$

\section{A.3. Comparative statics}

The first-order condition can be solved for $b$ and the optimum, $b^{*}$, expressed as a function of the parameters in the price equation:

$$
b^{*}=b^{*}(w, t, e, r)
$$

How does $b^{*}$ respond to an exogenous change in these parameters? Substituting $b^{*}$ into the first order condition and differentiating with respect to the relevant parameter yields the following comparative static results, if the assumptions involving the second-order conditions still hold:
(1) $\frac{\partial b^{*}}{\partial w}=\frac{-\frac{e(1+z)}{t(1-r)} \alpha_{b}\left[\delta_{P}+\frac{(\alpha-c) \delta_{P P}}{1-r}\right]}{S}<0$
(2) $\frac{\partial b^{*}}{\partial e}=\frac{-\frac{w(1+z)}{t(1-r)} \alpha_{b}\left[\delta_{P}+\frac{(\alpha-c) \delta_{P P}}{1-r}\right]}{S}<0$
(3) $\frac{\partial b^{*}}{\partial t}=\frac{\frac{e w(1+z)}{t^{2}(1-r)} \alpha_{b}\left[\delta_{P}+\frac{(\alpha-c) \delta_{P P}}{1-r}\right]}{S}>0$
(4) $\frac{\partial b^{*}}{\partial r}=\frac{-\frac{P}{(1-r)} \alpha_{b}\left[\delta_{P}+\frac{(\alpha-c) \delta_{P P}}{1-r}\right]}{S}<0$

How would prices respond to an exogenous change in one of these parameters? Taking the example of labor productivity: 


$$
\frac{\partial P}{\partial t}=\frac{\alpha_{b}}{1-r} \frac{\partial b^{*}}{\partial t}-\frac{e w(1+z)}{t^{2}(1-r)}
$$

Using the comparative static results above, the first term is positive while the second term is negative. We would generally expect productivity improvements to reduce prices. However, a special case, in which prices increase with higher labor productivity, is possible. This would tend to happen when demand is price inelastic, marginal rents associated with branding are high, and the optimal level of branding is very responsive to reductions in production costs. 


\section{Appendix B}

In order to estimate income and price elasticities of import demand, all variables are expressed as natural logs. Augmented-Dickey Fuller and Phillips-Perron tests for unit roots reveal that all of the variables are non-stationary. However, first-differences of the variables are stationary. This raises the possibility that a cointegrating relationship exists in which a linear combination of the variables is stationary. Therefore, the import demand relationship is estimated using an error-corrections model:

$$
\text { (10) } d M^{t}=\alpha+\beta_{1} d P_{m}^{t}+\beta_{2} d Y^{t}+\beta_{3}\left(M^{t-1}-\alpha^{\prime}-\gamma_{1} P_{m}^{t-1}-\gamma_{2} Y^{t-1}\right)+\mu^{t}
$$

in which $\mathrm{M}^{\mathrm{t}}$ represents real imports, $\mathrm{P}_{\mathrm{m}}^{\mathrm{t}}$ represents relative import prices, and $\mathrm{Y}^{\mathrm{t}}$ represents real income in time ' $t$ '. When variables are preceded by the operator ' $d$ ' it indicates the variables are expressed in first-differences.

An error-correction model is useful in that it allows us to model long-run equilibrium relationships between variables expressed as levels and short-run fluctuations around the equilibrium using differenced variables. The long-run equilibrium relationship (the error correction term) is contained in parentheses following the parameter $\beta_{3}$ in the above model, in which $\beta_{3}$ is expected to be negative. The intuition behind the model is straight-forward. If imports, $\mathrm{M}$, lie above the equilibrium relationship with prices, $\mathrm{P}$, and income, $\mathrm{Y}$, the error correction term would have a net positive value and the change in $\mathrm{M}$ in the subsequent period would be negative. If $\mathrm{M}$ lies below the equilibrium level, just the opposite would occur. When the system is in equilibrium there would be no impetus for import demand to change.

Table B1 contains the results of the estimates. Model 1a is an OLS estimation of the long-run relationship in levels, using an autoregressive distributed lag structure. If a cointegrating relationship exists, then the residuals of the equation, calculated using the estimated long-run coefficients, should be stationary, even though the variables expressed in levels are non-stationary. ${ }^{27}$ Both augmented-Dickey Fuller and Phillips-Perron tests for unit roots show that these residuals are indeed stationary. Model $1 \mathrm{~b}$ estimates the corresponding error-correction model, including the lagged residuals as the errorcorrection term. Note that all variables included in this estimation are stationary. In the error-correction model, the coefficients on the income and relative price variables are significant and have the correct sign. Furthermore, the coefficient on the error-correction term has the expected negative sign - suggesting a stable equilibrium relationship exists.

Model 2 repeats the same estimation as Model 1, except that lagged terms with insignificant coefficients are dropped. Again, augmented-Dickey Fuller and PhillipsPerron tests show that the residuals of the long-run model are stationary. In both the longrun OLS and the error-correction models, the coefficients on the income and relative

27 That is, a linear combination of the variables, using a vector of the long-run coefficients in the model, must be non-stationary for this specific cointegrating relationship to exist. 
price variables are significant and have the expected sign. The coefficients on the variables in the error-correction model represent the short-run demand elasticities with respect to income and price - that is, an income elasticity of 0.63 and a price elasticity of -0.61 . Long-run demand elasticities can be derived from the equilibrium solution of Model 2a. That is, the estimated coefficients on the variables expressed in levels are divided by one minus the coefficient on the lagged endogenous variable, since Imports $t_{t}$ must equal Imports $\mathrm{t}_{\mathrm{t}-1}$ in equilibrium. For example, the long-run income elasticity is 0.3749 divided by 0.1422 , or 2.64 . Both short-run and long-run elasticities are presented in Table 2 in the main text.

Table B1

Estimates of U.S. import demand elasticities, error-correction model with cointegrated variables, 1982:2 to 2002:1, t-statistics in parentheses.

\begin{tabular}{|c|c|c|c|c|}
\hline & \multicolumn{2}{|c|}{ Model 1} & \multicolumn{2}{|c|}{ Model 2} \\
\hline & (1a) & (1b) & (2a) & (2b) \\
\hline & $\begin{array}{l}\text { Long-run } \\
\text { (OLS) }\end{array}$ & $\begin{array}{c}\text { Error } \\
\text { correction }\end{array}$ & $\begin{array}{c}\text { Long-run } \\
\text { (OLS) }\end{array}$ & $\begin{array}{c}\text { Error } \\
\text { correction }\end{array}$ \\
\hline Imports $_{t-1}$ & $\begin{array}{l}0.9547 \\
(7.60) \\
\end{array}$ & & $\begin{array}{c}0.8578 \\
(15.55) \\
\end{array}$ & \\
\hline Imports $_{t-2}$ & $\begin{array}{c}-0.0812 \\
(-0.69)\end{array}$ & & & \\
\hline Rel. import price $_{t}$ & $\begin{array}{l}-0.5273 \\
(-1.76) \\
\end{array}$ & $\begin{array}{c}-0.6110 \\
(-2.21) \\
\end{array}$ & $\begin{array}{c}-0.4158 \\
(-3.92) \\
\end{array}$ & $\begin{array}{c}-0.6110 \\
(-2.21) \\
\end{array}$ \\
\hline Rel. import price ${ }_{t-1}$ & $\begin{array}{l}0.1635 \\
(0.49) \\
\end{array}$ & & & \\
\hline Real disposable income ${ }_{t}$ & $\begin{array}{c}0.5680 \\
(1.65)\end{array}$ & $\begin{array}{c}0.6461 \\
(2.18)\end{array}$ & $\begin{array}{l}0.3749 \\
(2.25)\end{array}$ & $\begin{array}{l}0.6289 \\
(2.12)\end{array}$ \\
\hline Real disposable income $_{t-1}$ & $\begin{array}{c}-0.2290 \\
(-0.69)\end{array}$ & & & \\
\hline Error correction $_{t-1}$ & & $\begin{array}{c}-0.1298 \\
(-3.46)\end{array}$ & & $\begin{array}{l}-0.1245 \\
(-3.48)\end{array}$ \\
\hline Constant & $\begin{array}{c}-0.5579 \\
(-1.63) \\
\end{array}$ & $\begin{array}{c}0.0010 \\
(0.18) \\
\end{array}$ & $\begin{array}{l}-0.6062 \\
(-2.04) \\
\end{array}$ & $\begin{array}{l}0.0002 \\
(0.04)\end{array}$ \\
\hline$R^{2}$ & 0.996 & 0.187 & 0.997 & 0.188 \\
\hline Durbin-Watson & 1.99 & 1.87 & 1.74 & 1.88 \\
\hline$N$ & 78 & 79 & 79 & 79 \\
\hline
\end{tabular}

Data sources are described beginning on page 21 of the main text. 


\section{Appendix C}

In order to gauge to what extent changes in output and real wages impact employment in the global apparel industry, a panel data set covering 49 countries over the years 1981 to 1996 was assembled using data from the 2001 3-digit ISIC Industrial Statistics Database of the United Nations Industrial Development Organization (UNIDO) and the World Development Indicators 2001 CD-ROM from the World Bank. This dataset included annual measurements of employment, real wages, and real output for the apparel industries in the countries for which complete data were available. All variables were expressed in natural logarithms. Using the general method of moments (GMM) technique developed by Arellano and Bond (1991) for the estimation of dynamic panels, the following model was estimated in which employment $\left(\mathrm{E}_{\mathrm{i}, \mathrm{t}}\right)$ is expressed as a function of real wages $\left(\mathrm{w}_{\mathrm{i}, \mathrm{t}}\right)$, real output $\left(\mathrm{y}_{\mathrm{i}, \mathrm{t}}\right)$, and country-specific effects $\left(\mathrm{v}_{\mathrm{i}}\right)$ :

$$
\mathrm{E}_{\mathrm{i}, \mathrm{t}}=\alpha+\delta \mathrm{E}_{\mathrm{i}, \mathrm{t}-1}+\beta_{\mathrm{x}} \mathrm{w}_{\mathrm{i}, \mathrm{t}-\mathrm{x}}+\gamma_{\mathrm{x}} \mathrm{y}_{\mathrm{i}, \mathrm{t}-\mathrm{x}}+v_{\mathrm{i}}+\mu_{\mathrm{i}, \mathrm{t}}, \text { for } \mathrm{x}=0 \ldots 1
$$

Lags of one and two years were included for the wage and output variables. The GMM estimation for dynamic panels involves expressing the equation in first-differences. Since wages and output cannot be taken as strictly exogenous, lagged values for these variables, expressed in levels, were used as instruments in the estimation.

Table C1. GMM estimates of dynamic labor demand equations for the apparel industries of 49 countries, 1981-96, $n=686$, $t$-statistics in parentheses.

\begin{tabular}{|c|c|c|c|}
\hline Variable & $\underline{\operatorname{Lag}}$ & (1) One-step & (2) Two-step \\
\hline Employment & $\mathrm{E}_{\mathrm{i}, \mathrm{t}-1}$ & $\begin{array}{l}0.6060 \\
(14.24)\end{array}$ & $\begin{array}{l}0.6073 \\
(29.41)\end{array}$ \\
\hline Real wages & $\mathrm{w}_{\mathrm{i}, \mathrm{t}}$ & $\begin{array}{c}-0.3789 \\
(-7.51)\end{array}$ & $\begin{array}{c}-0.3779 \\
(-21.01)\end{array}$ \\
\hline \multirow{3}{*}{ Real output } & $\mathrm{w}_{\mathrm{i}, \mathrm{t}-1}$ & $\begin{array}{l}0.1266 \\
(2.59)\end{array}$ & $\begin{array}{c}0.1379 \\
(16.52)\end{array}$ \\
\hline & $y_{i, t}$ & $\begin{array}{c}0.4854 \\
(12.55)\end{array}$ & $\begin{array}{l}0.4924 \\
(51.09)\end{array}$ \\
\hline & $\mathrm{y}_{\mathrm{i}, \mathrm{t}-1}$ & $\begin{array}{c}-0.1466 \\
(-3.23)\end{array}$ & $\begin{array}{l}-0.1543 \\
(-11.93)\end{array}$ \\
\hline Constant & & $\begin{array}{c}-0.0038 \\
(-3.42)\end{array}$ & $\begin{array}{c}-0.0034 \\
(-9.79)\end{array}$ \\
\hline \multicolumn{2}{|c|}{$\begin{array}{l}\text { Wald } \chi \text {-squared (all coefficients) } \\
\text { Sargan autocorrelation test }\end{array}$} & $\begin{array}{c}1774.56 \\
-8.79 \\
(\mathrm{p}-\text {-value }<0.001)\end{array}$ & $\begin{array}{c}27684.79 \\
-2.81 \\
\text { (p-value }=0.0049)\end{array}$ \\
\hline
\end{tabular}

The results are presented in Table C1. Note that both one-step and two-step GMM estimations are presented. While the two-step procedure can achieve some efficiency 
gains, standard errors may be underestimated. Therefore, the one-step results can be more reliable for drawing inferences about the coefficient estimates.

Wald tests show that the sum of the coefficients on the wage variables and the output variables are statistically significant and have the expected signs - that is, increases in real wages have a negative impact on employment while increases in real output have a positive impact. For the one-step GMM estimators, the Wald test of the null hypothesis that the coefficients were not statistically different from zero yielded a test statistic for the real wage variables of $\chi 2(2)=75.51(p$-value $<0.001)$ and a test statistic for the real output variables of $\chi 2(3)=180.53$ ( $p$-value $<0.001)$. The Wald test of the null hypothesis that the sum of the coefficients were equal to zero yielded a test statistics of $\chi 2(1)=48.96$ for real wages and $\chi 2(1)=74.05$ for real output. In interpreting the results, it is helpful to summarize the estimates in a more user-friendly fashion. For example, from these results, we can develop long-run estimates of the impact of changes in real wages and output on employment. These calculations, based on the two-step GMM procedure, are presented in Table $\mathrm{C} 2$. Because all variables were expressed in logarithm form, these coefficients can be interpreted as elasticity estimates.

The long-run coefficient on real wages is -0.611 . This means that a $10 \%$ increase in real wages would be associated with a $6.1 \%$ decrease in employment, other factors remaining constant. Likewise, a $10 \%$ increase in output is associated with a $8.6 \%$ increase in employment. Therefore, holding other factors constant, including unobserved country-specific effects, an increase in real wages does appear to have a negative impact on employment in the apparel sector. However, the response is inelastic - that is, the decrease in employment is of a lesser magnitude than the increase in real wages.

Table C2. Elasticity of labor demand estimates, long run estimates based on the results in Table 1

\begin{tabular}{|c|c|}
\hline Variable & Long-run coefficient estimate \\
\hline Real wages & -0.611 \\
\hline Real output & 0.861 \\
\hline
\end{tabular}

